\title{
Ecological stoichiometry in the microbial food web: a test of the light:nutrient hypothesis
}

\author{
J. J. Elser ${ }^{1, *}$, M. Kyle ${ }^{1}$, W. Makino ${ }^{2}$, T. Yoshida ${ }^{2,3}$, J. Urabe ${ }^{2}$ \\ ${ }^{1}$ Department of Biology, Arizona State University, Tempe, Arizona 85287-1501, USA \\ ${ }^{2}$ Center for Ecological Research, Kyoto University, Kamitanakami Hirano, Otsu 520-2113, Japan \\ ${ }^{3}$ Present address: Department of Ecology and Evolutionary Biology, Cornell University, Ithaca, New York 14853, USA
}

\begin{abstract}
The 'light:nutrient hypothesis' (LNH) states that the importance of the microbial food web relative to grazing impacts by macrozooplankton and the nature of the relationship between algae and bacteria (competition or commensalism) are affected by the balance of light and nutrients experienced by phytoplankton. We tested this hypothesis in field enclosures by manipulating irradiance and nutrient supply in a P-limited lake in Ontario, Canada. Shading and P-enrichment had little effect on standing biomass of small suspended particles $(<1 \mu \mathrm{m})$ but both decreased C:P ratio in this size fraction. P-fertilization had no effect on algal biomass or bacterial abundance but shading significantly lowered algal biomass and the ratio of algal biomass to bacterial abundance. Shading had no effect on heterotrophic nanoflagellates (HNF) but HNF abundance declined strongly with P-enrichment under both shaded and unshaded conditions, coincident with large increases in macrozooplankton biomass that accompanied P-fertilization. Shading and nutrient enrichment also affected resource limitation as indicated by dilution bioassays. Increased algal light limitation in the enclosures was associated with lower seston C:P ratio, as expected under the LNH. In addition, the C:P ratio of new seston produced in bioassay bottles was also affected by enclosure treatment; unshaded enclosures generally produced seston with moderately high C:P ratio while shaded enclosures produced new seston at low C:P under low ambient light but at very high C:P ratio when algae were incubated at higher light. Our data provide support for some aspects of the LNH, including predicted impacts on the microbial loop and on resource limitations and C:P stoichiometry. However, some responses were not consistent with the $\mathrm{LNH}$, indicating that the hypothesis needs to be modified to incorporate potential indirect effects.
\end{abstract}

KEY WORDS: Microzooplankton $\cdot$ Stoichiometry $\cdot$ Light $\cdot$ Phosphorus $\cdot$ Bacteria

Resale or republication not permitted without written consent of the publisher

\section{INTRODUCTION}

The microbial food web is widely recognized as a key conduit of energy and material flows in pelagic ecosystems (Azam et al. 1983, Sherr \& Sherr 1991, Hwang \& Heath 1997, Cotner \& Biddanda 2002). For example, phytoplankton exude labile organic matter (as dissolved organic carbon, DOC) and thus support trophic pathways involving bacteria, bacterivorous flagellates, and eventually larger consumers (Azam et al. 1983, Güde 1989, Guerrini et al. 1998). While such microbial connections are omnipresent, their importance relative to the conventional 'grazing chain' appears to vary among systems for reasons that are poorly understood. Bacteria and algae are often thought to exist in a loose mutualism, where algae provide DOC to support bacterial growth while bacteria remineralize organically bound nutrients to support phytoplankton production. However, the mutualistic scenario between bacteria and phytoplankton is complicated by the fact that, in many cases, bacteria are not the primary remineralizers of organically bound nutrients (Azam et al. 1983, Ferrier Pages \& Rassoulzadegan 1994, Vadstein 2000) and bacteria can compete with algae for inorganic nutrients (Currie \& Kalff 1984, Cotner \& Wetzel 1992). In addition, it 
appears that in many situations bacterial production is not limited by DOC but by the supply of key nutrients, such as N or especially P (Morris \& Lewis 1992, Elser et al. 1995b, Cotner et al. 1997, Vadstein 2000, Carlsson \& Caron 2001). Under such conditions the relationship between bacteria and phytoplankton is not mutualistic $(+,+)$ but competitive $(-,-)$. Indeed, in chemostat experiments bacteria rapidly outcompete phytoplankton for inorganic nutrients when the supply of labile DOC is high relative to the supply of nutrients (Bratbak \& Thingstad 1985, Grover 1997, 2000).

In addition to the intensive study of factors influencing the resource interactions of algae and bacteria in the pelagic zone, aquatic studies (Güde 1989, Sanders \& Wickham 1993, Jürgens 1994, Pace \& Cole 1996, Cole 1999, Langenheder \& Jürgens 2001) have quantified the impact of microzooplankton on both algae and bacteria and attempted to understand the factors influencing the relative importance of 'conventional' trophic links in the pelagic food web (algae to macrozooplankton to fish) relative to the 'microbial loop' (algal DOC and detritus to bacteria to small protozoa to macrozooplankton to fish). The dominance of these 2 pathways is known to vary with trophic structure; for example, in lake food webs where macrozooplankton are suppressed by fish predation, microzooplankton play a dominant role in applying grazing pressure on bacteria and small phytoplankton (Jürgens 1994, Pace \& Cole 1996). Trophic status also appears to be of importance, as the microbial food web appears to play a proportionately larger role in trophic interactions in oligotrophic relative to eutrophic conditions (Cotner \& Biddanda 2002). Finally, microbial interactions play a key role in nutrient cycling in the pelagic zone and indeed, it now appears that in many situations nutrients are remineralized primarily by bacterivorous flagellates (Rothaupt 1992, Vadstein 2000) and not by bacteria themselves, which is consistent with the strong tendency of bacteria to experience nutrient limitation. What emerges from these developments is a picture of a complex set of internal and external interactions connecting pelagic trophic interactions with nutrient cycling and resulting in considerable variation among ecosystems in the relative importance of various pathways and dominant players.

To explain this variation in the context of these complex factors, Sterner et al. (1997) proposed a 'light:nutrient' hypothesis (LNH) pertaining to the relationships between algae and bacteria, the relative importance of the microbial food web, as well as the production and community composition of metazoan zooplankton in lakes. They proposed that variations in the supply balance of solar radiation and key inorganic nutrients (such as $\mathrm{PO}_{4}$ ) alter the severity of nutrient limitation of phytoplankton growth, with subsequent effects on metazoan herbivores and the microbial food web. More specifically, high light:nutrient supply ratios should accentuate algal nutrient limitation, as increased light increases phytoplankton demand for nutrients (by raising algal potential growth rate, $\mu_{m}$ i Shuter 1979) that may not be matched by ambient supply processes. One consequence of these responses is increased biomass $\mathrm{C}$ :nutrient ratio in algal biomass. Conversely, low light:nutrient ratios should promote phytoplankton light limitation, leading to low $\mu_{\mathrm{m}}$ and more easily allowing nutrient supply to keep pace with algal demand. As a result, algal C:nutrient ratios should be low and roughly in Redfield proportions. Such changes in the severity of algal nutrient limitation should affect the microbial food web in 2 ways. First, algae with high C:nutrient ratios are poor food for zooplankton (Sterner \& Hessen 1994, Elser et al. 2001). Thus, macrozooplankton production should be impaired, which should increase the importance of microbial trophic links as protozoa and ciliates would no longer be suppressed due to consumption by macrozooplankton. Second, severely nutrient-limited (especially P-limited) phytoplankton tend to increase their exudation of labile organic carbon (Lancelot 1983, Obernosterer \& Herndl 1995, Guerrini et al. 1998, Berman-Frank \& Dubinsky 1999, Corzo et al. 2000), which increases DOC availability to bacteria and shifts the resource limiting bacterial growth from DOC to inorganic nutrients, thus shifting the competitive advantage from algae to bacteria. Therefore, bacteria should have greater relative abundance, compared to algae, in systems with high light:nutrient ratio (Sterner et al. 1997).

To date, various components of the LNH have been tested, primarily in laboratory settings. For example, effects of light:nutrient balance on Daphnia growth (Urabe \& Sterner 1996) and population dynamics (Sterner et al. 1998) have been demonstrated in laboratory settings involving $\mathrm{PO}_{4}$ limitation of algae. In these experiments, increased light inhibited Daphnia performance by raising algal C:P ratios above optimal levels. In the study of Urabe \& Sterner (1996), a clear interaction between light and $\mathrm{PO}_{4}$ supply was observed, as higher light intensities were required to inhibit Daphnia growth as $\mathrm{PO}_{4}$ availability increased. Such effects have now been demonstrated for natural conditions (Urabe et al. 2002b) in an experiment in which a 10 -fold reduction in incoming solar radiation to field enclosures resulted in a 5-fold increase in zooplankton production due to an improvement in stoichiometric food quality. This experiment also demonstrated a light-nutrient interaction, as lowering irradiance at high $\mathrm{PO}_{4}$ inputs resulted in decreased zooplankton production due to lowered overall abundance of food. Thus, the predictions from the LNH for 
macrozooplankton dynamics seem well-supported by available data.

However, evidence regarding effects of light:nutrient balance on components of the microbial food web is limited. Sterner et al. (1998) reported no effect of altered irradiance on bacterial abundance and production in their artificial ecosystem experiment. In laboratory experiments involving mixed bacteria assemblages and the green alga Scenedesmus, Gurung et al. (1999) showed that bacteria resource limitation was influenced by both light and $\mathrm{PO}_{4}$ supplies, with DOClimitation generally strongest at low light and high $\mathrm{PO}_{4}$ supply, while $\mathrm{PO}_{4}$-limitation was strongest at high light and low $\mathrm{PO}_{4}$ inputs. Furthermore, they showed that the dominance of bacteria relative to algae decreased with increasing light (contrary to the LNH) but increased with increasing $\mathrm{PO}_{4}$ supply at low irradiance (consistent with the LNH). While these results provide provisional support for some aspects of the LNH, they involved laboratory settings with unialgal cultures in the absence of higher trophic levels, including protozoa and macrozooplankton. Thus, to date there have been few tests of microbial aspects of the LNH under natural conditions and over ecologically significant time scales. However, an observational study has recently appeared (Chrzanowski \& Grover 2001), on bacterial resource limitation in 2 Texas reservoirs. They reported results generally consistent with the LNH, in that bacterial growth was more likely to be Pthan DOC-limited during periods when epilimetic light:nutrient ratios were high. To examine how changes in environmental light and nutrient supplies affect food web structure in pelagic ecosystems, we performed a large in situ enclosure experiment in a Canadian Shield lake. Since major responses of total seston stoichiometry and zooplankton production in this experiment have already been presented elsewhere (Urabe et al. 2002b), here we report responses of microbial food web components to achieve a more complete assessment of the responses of the whole planktonic food web to these factors.

\section{MATERIALS AND METHODS}

Study site. Experimental manipulations were maintained for 26 d from 8 July to 3 August 1999 in Lake 239 (L239 hereafter), a relatively large (56 ha, $30 \mathrm{~m}$ maximum depth) oligotrophic lake $(\mathrm{TP}=\sim 0.17 \mu \mathrm{M})$ at the Experimental Lakes Area (ELA), northwestern Ontario, Canada $\left(93^{\circ} 30^{\prime}\right.$ to $94^{\circ} 00^{\prime} \mathrm{W}, 49^{\circ} 30^{\prime}$ to $49^{\circ} 45^{\prime} \mathrm{N}$, altitude 360 to $380 \mathrm{~m}$ above sea level). Concentrations of dissolved inorganic nitrogen and silica are relatively high in lakes of the ELA and thus P has long been recognized as the key limiting nutrient in these systems (Schindler 1977, Schindler et al. 1978). Consistent with overall scarcity of $\mathrm{P}$, seston $\mathrm{C}$ :P ratios in the euphotic zone of ELA lakes are high and have been directly linked to mineral (P) limitation of zooplankton growth (Elser et al. 2001). Macrozooplankton in L239 comprise various calanoid and cyclopoid copepods (including Diaptomus minutus, Diacyclops bicuspidatus thomasi) and a mixed cladoceran assemblage (Bosmina longirostris, Holopedium gibberum, and Daphnia mendotae). L239 phytoplankton are diverse, with substantial contributions of, in declining order of relative dominance, chrysophytes, dinoflagellates, cyanophytes, diatoms, and cryptophytes (Elser et al. 2001, D. Findlay unpubl. data). Little previous work has examined the lake's microbial components.

Design and execution of mesocosm experiment. Details of the experimental enclosures and overall execution of the experiment are described by Urabe et al. (2002b). Briefly, enclosures consisted of $1 \mathrm{~m}$ diameter, $4 \mathrm{~m}$ deep, clear polyethylene tubes (closed on the bottom, total volume $3.1 \mathrm{~m}^{3}$ ). At the time of the experiment, the mixed-layer depth in L239 was $4.5 \mathrm{~m}$. Enclosures were filled by pumping water from a depth of $2 \mathrm{~m}$ and passing it through $125 \mu \mathrm{m}$ mesh Nitex. Live zooplankton from L239 were collected using horizontal tows of a $125 \mu \mathrm{m}$ zooplankton net and combined with collections of Daphnia dentifera from nearby Lake 979. This species was added to assure the presence of a large-bodied daphnid in all enclosures. Subsamples of this collection were added to each enclosure to bring the initial macrozooplankton biomass to a level similar to that found in L239. To manipulate irradiance we covered the top and sides of 6 of 12 enclosures with neutral density screening (shaded treatment) and left the remaining enclosures uncovered (unshaded treatment). The screening lowered photosynthetically active radiation (PAR) to $7 \%$ of ambient levels. This reduction in incident light is roughly equivalent to that experienced by a lake during a period of deeply overcast skies. Each enclosure was also covered with a $1.25 \mathrm{~m}$ square of OP3 Plexiglas to eliminate incident ultraviolet (UV) radiation and thus prevent confounding effects of lowering total irradiance with potential effects of also lowering UV. Direct measurements of underwater PAR using a Li-Cor $2 \pi$ underwater sensor along with a $2 \pi$ deck cell indicated that intensities at $1 \mathrm{~m}$ depth were 20 to $40 \%$ of surface radiation in unshaded enclosures but ranged from 3 to $6 \%$ in shaded enclosures. Effects of nutrients were examined by creating a gradient of nutrient inputs in both shaded and unshaded enclosures. These nutrient gradients were created by adding $\mathrm{PO}_{4}$ at 6 concentrations $(0$, $0.024,0.048,0.097,0.19$, and $0.39 \mu \mathrm{M}$, with 1 enclosure per nutrient treatment within each irradiance treatment). This range of $\mathrm{PO}_{4}$ enrichment was chosen based 
on previous assessment of seston $\mathrm{C}$ concentrations in L239 so that we could expect seston C:P ratios to decrease substantially to levels lower than those likely to be limiting to daphnids (e.g. <250:1, Urabe \& Watanabe 1992). $\mathrm{PO}_{4}$ was added only once (as $\mathrm{KH}_{2} \mathrm{PO}_{4}$ ) at the beginning of the experiment and produced a rapid decrease in total seston C:P (Urabe et al. 2002b). $\mathrm{PO}_{4}$ fertilization treatments were not replicated in order to achieve a broad range of experimental $\mathrm{PO}_{4}$ levels; statistical analyses rested on regression analyses (to test for effects of added $\mathrm{PO}_{4}$ ) and pair-wise $t$-tests (to test for effects of light), as described below and in Urabe et al. (2002b). Inorganic $\mathrm{N}$ was also added (as $\mathrm{NH}_{4} \mathrm{NO}_{3}$ ) to all enclosures at an atomic ratio of 30 to ensure that $\mathrm{P}$ remained the limiting nutrient in the enclosures. The experiment ran for $26 \mathrm{~d}$. While somewhat long relative to time scales of microbial response, this time span was necessary to permit potential changes in macrozooplankton to occur (Urabe et al. 2002b). Calculation of total $\mathrm{P}$ at the end of the experiment to determine if added $\mathrm{P}$ was present in water column pools (total dissolved, seston, zooplankton) indicated that, while there were no differences between shaded and unshaded enclosures in the relative importance of 'missing' P (i.e. P that is not accounted for in water column $\mathrm{P}$ pools), the relative amount of missing $\mathrm{P}$ increased with P-fertilization level in both shaded and unshaded enclosures (from negligible in enclosures receiving less than $0.097 \mu \mathrm{M} P$ to more than $2 / 3$ in the highest fertilization treatment). We cannot determine if this missing $\mathrm{P}$ was associated with accumulated materials at the bottom of the enclosures, which we probably under-sampled despite enclosure mixing, or with wall growth. However, observable wall growth was minimal during the experiment and thus we suspect that an increasing fraction of $\mathrm{P}$ was sedimented in the high $\mathrm{P}$ enclosures. Thus, in keeping with general recommendations for interpreting mesocosm experiments given potential enclosure effects (Schindler 1998), results for our high fertilization treatments should be treated with some caution given that the fate of added $\mathrm{P}$ is relatively uncertain in these bags. However, the ecologically relevant results that pertain most closely to field conditions at the ELA are for the low-enrichment enclosures; in these enclosures, we were able to account for $>85 \%$ of the added $\mathrm{P}$.

Response variables. Abundance and stoichiometry of plankton constituents and dissolved nutrients: Enclosures were mixed every day by pulling a $0.3 \mathrm{~m}$ perforated PVC disk several times through the length of the enclosure. Monitoring for a variety of parameters occurred at $5 \mathrm{~d}$ intervals. Methods of monitoring of macrozooplankton are described by Urabe et al. (2002b). Water samples for quantification of heterotrophic nanoflagellates (HNF, as an index of overall microzooplankton abundance), algae, bacteria, seston, and dissolved nutrient analysis were taken after each enclosure was mixed. HNF samples were preserved with $4 \%$ glutaraldehyde and kept refrigerated until enumeration by epifluorescent microscopy after staining with primulin (Caron 1983). Algal samples were fixed with Lugol's solution for later microscopic enumeration. Algal biomass was estimated by combining cell counts with taxon-specific cell-volume estimates following Findlay \& Kling (1998). Biovolume for algal taxa with variable morphology or colony sizes was estimated independently for each sample while single constant values were used for taxa that did not exhibit substantial variation in size and shape. Bacteria samples were preserved with $2 \%$ filtered formaldehyde and kept refrigerated until enumeration by epifluorescent microscopy using DAPI (4'6-diamidino-2phenylindole) staining following Porter \& Feig (1980). Thus our data pertain to responses of the entire microbial assemblage to experimental conditions. As previous studies have shown that manipulations of nutrients or grazing pressure can induce physiological and taxonomic shifts within the overall microbial assemblage (e.g. Jürgens et al. 1999, Larsen et al. 2001), this means that our results pertaining to microbial responses to light and nutrient manipulations will be essentially conservative; some potentially important responses may therefore have been missed.

Water samples for seston analysis were size-fractionated using a $1 \mu \mathrm{m}$ polycarbonate filter after which suspended particles in whole-water and $<1 \mu \mathrm{m}$ water were filtered onto pre-combusted GF/F glass-fiber filters and dried for later analysis (Elser et al. 1995a). Sestonic $\mathrm{C}$ concentration (seston [C] hereafter, units: $\mathrm{mg} \mathrm{C}$ $\mathrm{I}^{-1}$ ) was determined using infrared analysis of $\mathrm{CO}_{2}$ in headspace after filters were oxidized in sealed jars containing concentrated persulfate (Elser et al. 2001). Seston P was then analyzed colorimetrically (APHA 1992) and C:P ratios of the 2 seston size fractions were calculated and expressed as atomic ratios. Samples for analysis of dissolved chemical constituents were filtered through a $0.2 \mu \mathrm{m}$ polycarbonate filter and analyzed immediately for ammonium-N $\left(\mathrm{NH}_{4}{ }^{+}, \mathrm{NH}_{4}-\mathrm{N}\right.$ hereafter, Solorzano 1969) or kept frozen for later analysis of nitrate- $\mathrm{N}\left(\mathrm{NO}_{3}{ }^{-}, \mathrm{NO}_{3}-\mathrm{N}\right.$ hereafter) and soluble reactive phosphorus (SRP) according to standardized methods (Stainton et al. 1977). In our analysis, the detection limit for SRP was in the range of $0.065 \mu \mathrm{M}$.

Growth limitation of phytoplankton and bacteria: Resource limitation of phytoplankton (P vs light) and bacterial ( $\mathrm{P}$ vs DOC) growth was assessed in each enclosure at the end of the experiment using dilution bioassays (Sterner 1994, Elser et al. 1995b). Dilution reduces the encounter rate between algae and microzooplankton and thus permits a more direct measure of 
actual algal or bacterial growth rate. In both bacterial and phytoplankton assays, mixed enclosure water was filtered through $0.2 \mu \mathrm{m}$ cartridge filters and then whole enclosure water was combined with filtered water in a proportion of $1: 3$ (75\% dilution).

For phytoplankton assays, 2 sets of 4 clear PVC bottles $\left(\begin{array}{ll}1 & 1\end{array}\right)$ were then filled with diluted enclosure water. For each set, 2 bottles were enriched with $\mathrm{P}$ (+2 $\mu \mathrm{M}$ as $\mathrm{NaHPO}_{4}$, P hereafter; a concentration of $2 \mu \mathrm{M}$ was chosen to assure that saturation of algal uptake and growth kinetics was achieved) and the other 2 left as unenriched controls (C). One set of 4 bottles was incubated at $1 \mathrm{~m}$ depth in the enclosure (E hereafter) from which the original sample was taken while the other set (L) was incubated in L239 at a depth of $\sim 0.5 \mathrm{~m}$. Algal growth was assessed by measuring, for both initial diluted water and for water in bottles at the end of the incubation, seston [C] for materials captured on GF/C grade glass-fiber filters, which probably pass most bacterial cells (Chrzanowski et al. 1995, Elser et al. 1995a). Thus, we were able to assess the degree of algal P-limitation under the light conditions of the enclosure by comparing growth in control and $+\mathrm{P}$ bottles held in the enclosure (EC vs EP). We could also assess potential P-limitation under ample light by considering the bottles incubated at $0.5 \mathrm{~m}$ in L239 (LC vs LP). Finally, the approach allowed us to assess algal light limitation by comparing growth during incubation in the enclosure (where light might have been limiting, especially in shaded enclosures) to growth during incubation at elevated light intensities (EC vs LC). We were also able to assess whether responses to light were affected by P-enrichment. To assess how Penrichment and light manipulation in bioassays affected algal C:P stoichiometry, we also measured seston [P] as described above. This allowed us to estimate, for each enclosure, the C:P ratio of new algal biomass produced during the bioassay incubation period in different $\mathrm{P}$ and light manipulation bioassay treatments.

Bacterial growth response was measured using the same $75 \%$ diluted enclosure water prepared as described above. Diluted water was sub-sampled (in duplicate) for later enumeration of initial bacterial density and then used to fill eight $500 \mathrm{ml}$ bottles that were then subjected to a factorial enrichment of DOC (added as glucose and acetate in 1:1 molar proportion to achieve a final concentration of $250 \mu \mathrm{M} \mathrm{C}$ ) and $\mathrm{P}$ (added as $\mathrm{NaHPO}_{4}$ to a concentration of $2 \mu \mathrm{M}$ P). Two replicates of each treatment combination were prepared and there were 4 treatment combinations in all: 'controls' that received no DOC or $\mathrm{P}_{1}+\mathrm{P}$ that received $\mathrm{PO}_{4}$ only, $+\mathrm{DOC}$ that received DOC only, and $+\mathrm{DOC} \& \mathrm{P}$ that received both DOC and P. Bottles were held at lake temperature by suspending them at $0.5 \mathrm{~m}$ in L239.
Duplicate $10 \mathrm{ml}$ sub-samples were preserved for microscopic enumeration as described above. Bacterial growth was assessed by changes in bacteria numbers determined by epifluorescent microscopy.

Growth rates $(\mu)$ of algae and bacteria during the bioassays were calculated assuming exponential growth as:

$$
\mu\left(\mathrm{d}^{-1}\right)=\ln \left(C_{2} / C_{1}\right) / \mathrm{d} t
$$

where $C_{2}$ and $C_{1}$ represent abundance (algal [C] or bacteria numbers) at the end and beginning of the incubation, respectively, and $\mathrm{d} t$ is the duration of the incubation. Based on prior experience in these lakes (Sterner et al. 1995, Chrzanowski et al. 1997), incubations lasted $3 \mathrm{~d}$ for algae and $1 \mathrm{~d}$ for bacteria.

Data analysis. Analyses for monitored variables in the enclosures involved data from the final 3 sampling dates (last $2 \mathrm{wk}$ ) of the experiment. Examination of temporal data for major parameters such as seston [C] and macrozooplankton biomass indicated that temporal dynamics during this period were relatively modest (Urabe et al. 2002b), suggesting that the enclosures had reached some kind of quasi-equilibrium during the focal period considered. To indicate the extent of temporal variation of various response parameters during the final $2 \mathrm{wk}$ of the experiment, we present error bars as $\pm 1 \mathrm{SE}$ of the mean values observed during those final sampling dates. However, only the mean values of the data from the final sampling dates, and not the individual measurements in time, were used in statistical tests. Effects of enclosure P-enrichment were evaluated by regressing the mean values of each variable over the final sampling dates versus enclosure Penrichment level. Prior to regression, P-enrichment treatment was generally transformed as $\ln (P+1)$, where $\mathrm{P}$ is the $\mathrm{P}$-enrichment level for that enclosure. Effects of light were assessed by performing a single paired $t$-test for each parameter. This test evaluated the hypothesis that, across all P-enrichment levels, the difference between unshaded and shaded enclosures for each particular P-enrichment level for that parameter was zero.

Each bioassay experiment (algal response to light and $\mathrm{P}$, bacteria response to DOC and P) was analyzed by 2-way analysis of variance (ANOVA) to evaluate the statistical significance of main effects and interactions for each enclosure's experiment (degrees of freedom: 1 for main effects and interactions, 4 for the error term). Effects of enclosure irradiance treatment (e.g. shaded vs unshaded) were evaluated by a paired $t$-test of the particular enrichment bioassay response for each level of enclosure P-enrichment, as described above for routinely monitored variables. Here we considered the mean value of bioassay response in each shaded enclosure's assay relative to the unshaded 
enclosure at the same enrichment level and tested the null hypothesis, across all enclosures, that the difference between the values for shaded and corresponding unshaded enclosures was zero. Effects of enclosure P-enrichment treatment (e.g. 0 to $0.39 \mu \mathrm{M}$ P) were assessed by regressing bioassay responses vs enclosure P-enrichment treatment separately for each enclosure irradiance treatment; again, the data were generally transformed $[\ln (\mathrm{P}+1)]$ prior to regression.

\section{RESULTS}

\section{Dissolved nutrients}

At the end of the experiment, concentrations of $\mathrm{NO}_{3}$ $\mathrm{N}$ and $\mathrm{NH}_{4}-\mathrm{N}$ increased significantly with increasing level of fertilizer addition in both unshaded and shaded enclosures (Fig. 1A,B). However, this increase was muted in unshaded enclosures, especially for $\mathrm{NO}_{3}-\mathrm{N}$ (for $\mathrm{NO}_{3}-\mathrm{N}$, slopes of the regression lines for shaded and unshaded enclosures were significantly different, $\mathrm{p}$ $<0.05$ ) and in general shaded enclosures had higher concentrations of $\mathrm{NH}_{4}-\mathrm{N}$ and $\mathrm{NO}_{3}-\mathrm{N}$ than unshaded enclosures ( $\mathrm{p}<0.04$ for $\mathrm{NH}_{4}-\mathrm{N}, \mathrm{p}<0.09$ for $\mathrm{NO}_{3}-\mathrm{N}, \mathrm{p}<$ 0.01 for total inorganic nitrogen, $\mathrm{TIN}=\mathrm{NH}_{4}-\mathrm{N}+\mathrm{NO}_{3}-$ $\mathrm{N}$; data not shown). In contrast to strong increases in inorganic nitrogen with enclosure fertilization level, effects of increasing fertilizer input on SRP were modest (Fig. 1C) and statistically significant only in the shaded enclosures. Thus, phytoplankton and other microbes were able to efficiently sequester added $\mathrm{PO}_{4}$ under unshaded conditions, a result that is consistent with the strongly P-limited conditions of the lakes of the ELA (Schindler et al. 1978, Sterner et al. 1995). Because enrichment effects were stronger for $\mathrm{NO}_{3}-\mathrm{N}$ and $\mathrm{NH}_{4}-\mathrm{N}$ than for SRP, the N:P ratio of dissolved inorganic nutrients (as indexed by TIN:SRP) was generally higher at high enrichment levels (Fig. 1D; however, this tendency was statistically significant only for the shaded enclosures. A paired $t$-test indicated that TIN:SRP ratios were significantly higher in shaded relative to unshaded enclosures. In total, these data indicate that dissolved nutrient concentrations were affected not only by the experimental level of nutrient addition to the enclosures but also by irradiance, as decreased light levels allowed higher concentrations of nutrients to be maintained in the dissolved pool.
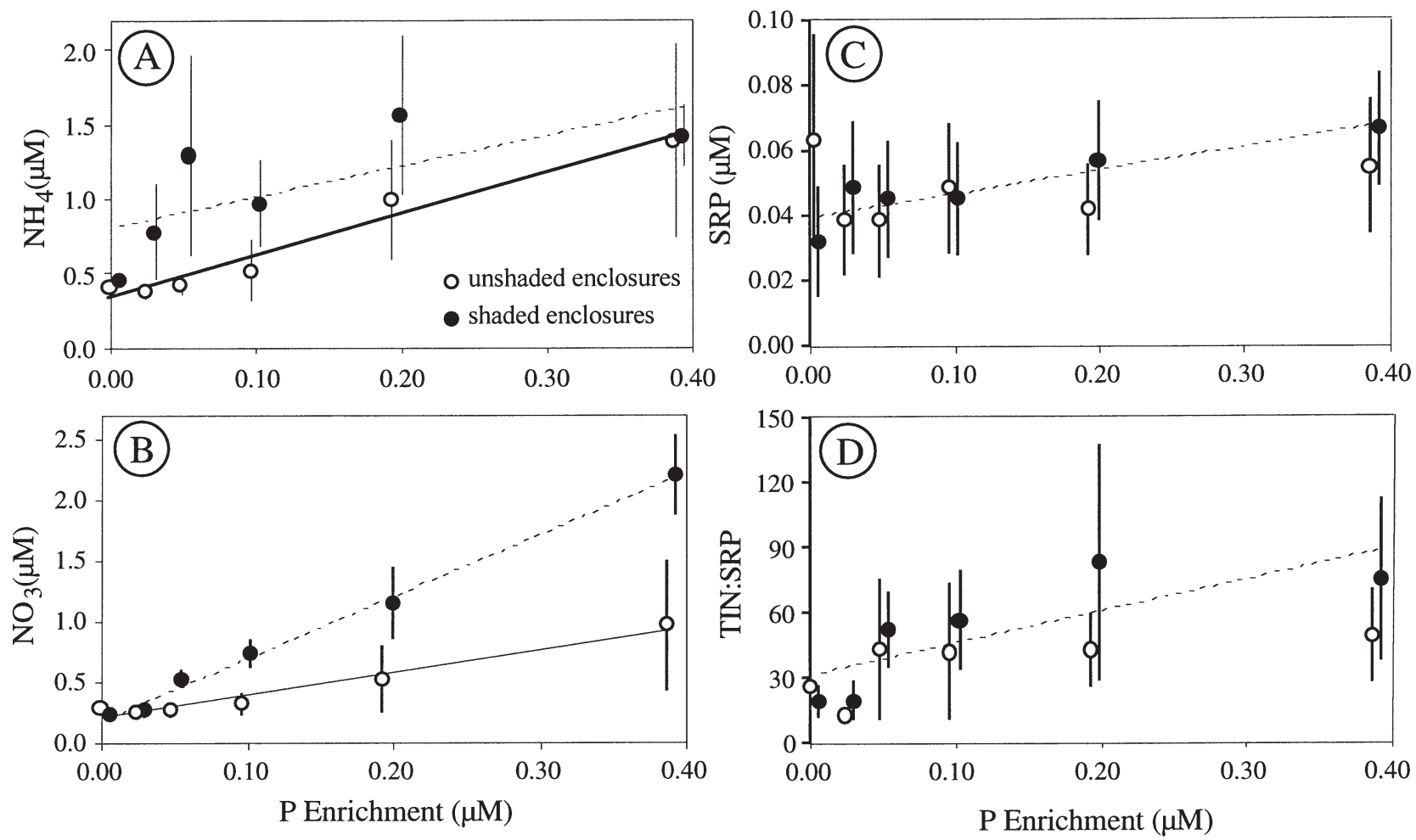

Fig. 1. Effects of shading and nutrient enrichment on (A) $\mathrm{NO}_{3}-\mathrm{N},(\mathrm{B}) \mathrm{NH}_{4}-\mathrm{N}$, (C) soluble reactive phosphorus (SRP), and (D) total inorganic nitrogen $\left(\mathrm{TIN}_{i} \mathrm{NH}_{4}-\mathrm{N}+\mathrm{NO}_{3}-\mathrm{N}\right)$ :SRP ratio in the enclosures. Error bars indicate $\pm 1 \mathrm{SE}$ of observations on the final 3 sampling dates. Lines indicate regression lines fit to the data (shown when statistically significant) for shaded enclosures (----) or unshaded enclosures (-). In all figures, data for shaded enclosures were displaced upwards slightly on the $x$-axis so that confidence limits for the shaded and unshaded enclosures can be more easily discerned at a given nutrient enrichment level 


\section{Seston abundance and C:P stoichiometry}

Changes in total seston abundance and C:P ratio were reported by Urabe et al. (2002b); we summarize those data here. Total seston $\mathrm{C}$ concentration ([C] hereafter) was generally unaffected by enclosure Pfertilization but, at each P-enrichment level, shaded enclosures had lower total seston [C]. Total seston C:P decreased strongly with increasing $\mathrm{P}$ enrichment in both unshaded and shaded enclosures. Shading generally lowered total seston C:P at all P-enrichment levels but the effect was larger at low P-enrichment levels (Urabe et al. 2002b). Seston in small particles (the 'bacteria' fraction, $<1 \mu \mathrm{m}$ ) was also affected by fertilization and light (Fig. 2). As for total seston [C], P enrichment had no effect on $<1 \mu \mathrm{m}$ [C] (Fig. 2A; regression statistics non-significant, $\mathrm{p}>0.10)$. However, unlike the response for total seston reported by Urabe et al. (2002b), shading had no effect on $<1 \mu \mathrm{m}$ seston [C] (Fig. 2; paired $t$-test, $\mathrm{p}>0.3$ ). However, both enrichment and shading appeared to affect C:P stoichiometry in the $<1 \mu \mathrm{m}$ fraction (Fig. 2B). Similar to the significant decline in total seston C:P reported by Urabe et al. (2002b), P-enrichment produced marginally significant declines in $<1 \mu \mathrm{m}$ seston $\mathrm{C}$ :P in both unshaded and shaded sets of enclosures ( $p=0.051$ for shaded enclosures, with $\mathrm{P}$-enrichment level transformed as $\ln (\mathrm{P}+1)$; $\mathrm{p}=0.089$ for unshaded enclosures, no transformations). Also similar to the response of whole seston (Urabe et al. 2002b), <1 $\mu$ m seston C:P was consistently lower in shaded than in unshaded enclosures (Fig. 2B; paired $t$-test, $\mathrm{p}<0.01)$. Thus, both $\mathrm{P}$-enrichment and shading affected the P-content of bacteria-sized particles in the enclosures.

\section{Balance of bacteria and phytoplankton}

Average algal biomass determined by microscopic examination over 3 of the final sampling dates (Days 200, 210, and 215; samples for Day 205 were lost) generally increased with increasing P-fertilization (Fig. 3A) but these trends were not statistically significant $(p \approx 0.20)$. However, algal biomass was generally lower in shaded relative to unshaded enclosures at each P-enrichment level (paired $t$-test, $\mathrm{p}<0.04$ ). Thus, algal biomass responded in a similar manner qualitatively to overall patterns of response of total seston abundance reported by Urabe et al. (2002b). Neither P-enrichment nor shading affected bacterial abundance in the enclosures $(\mathrm{p}>$ 0.70; Fig. 3B). Visual examination indicated that there were no systematic differences in bacterial cell size as a function of nutrient enrichment or irradiance and so bacterial numbers reasonably approximate bacterial biomass in the enclosures. The balance of bacteria relative to algae was assessed by calculating an index of algal dominance as the ratio of algal biomass to bacteria abundance (A:B ratio) for each sampling date. Mean values of A:B for 3 of the final sampling dates (Days 200, 210 and 215 ) were then analyzed with respect to effects of P-fertilization and irradiance manipulations. Contrary to expectations based on the LNH, there was no apparent effect of P-enrichment on the relative abundance of algae versus bacteria (Fig. 3C). However, despite relatively high variance in $A: B$ during the final sampling dates, shading produced a consistent reduction in $\mathrm{A}: \mathrm{B}(\mathrm{p}<0.03$ in paired $t$-test; Fig. $3 \mathrm{C}$ ), primarily due to the relatively large decreases in algal biomass in shaded enclosures. This result is inconsistent with expectations based on the LNH (Sterner et al. 1997), which predicts that increased light under nutrient limitation should enhance bacteria at the expense of algae due to increased supply of labile DOC from nutrient-limited algae, allowing bacteria to outcompete bacteria for inorganic P. However, the fact that differences in algal:bacteria ratio were due entirely to changes in algal biomass and that there were no treatment effects on bacterial numbers suggests that this outcome should be considered with some caution.

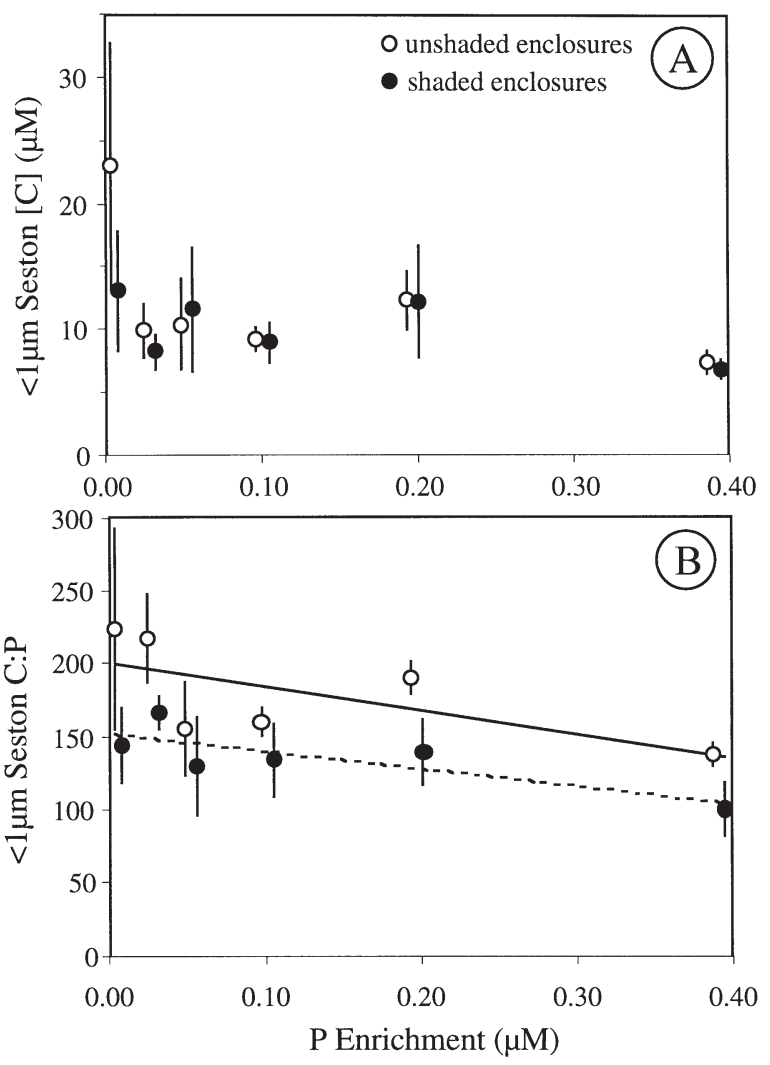

Fig. 2. Effects of experimental manipulations on (A) the abundance ( $\mu \mathrm{M} \mathrm{C}$ ) and (B) C:P ratio of 'bacteria-sized' seston (passing through a $1.0 \mu \mathrm{m}$ membrane filter but captured on a GF/F glass-fiber filter). Confidence limits as in Fig. 1 


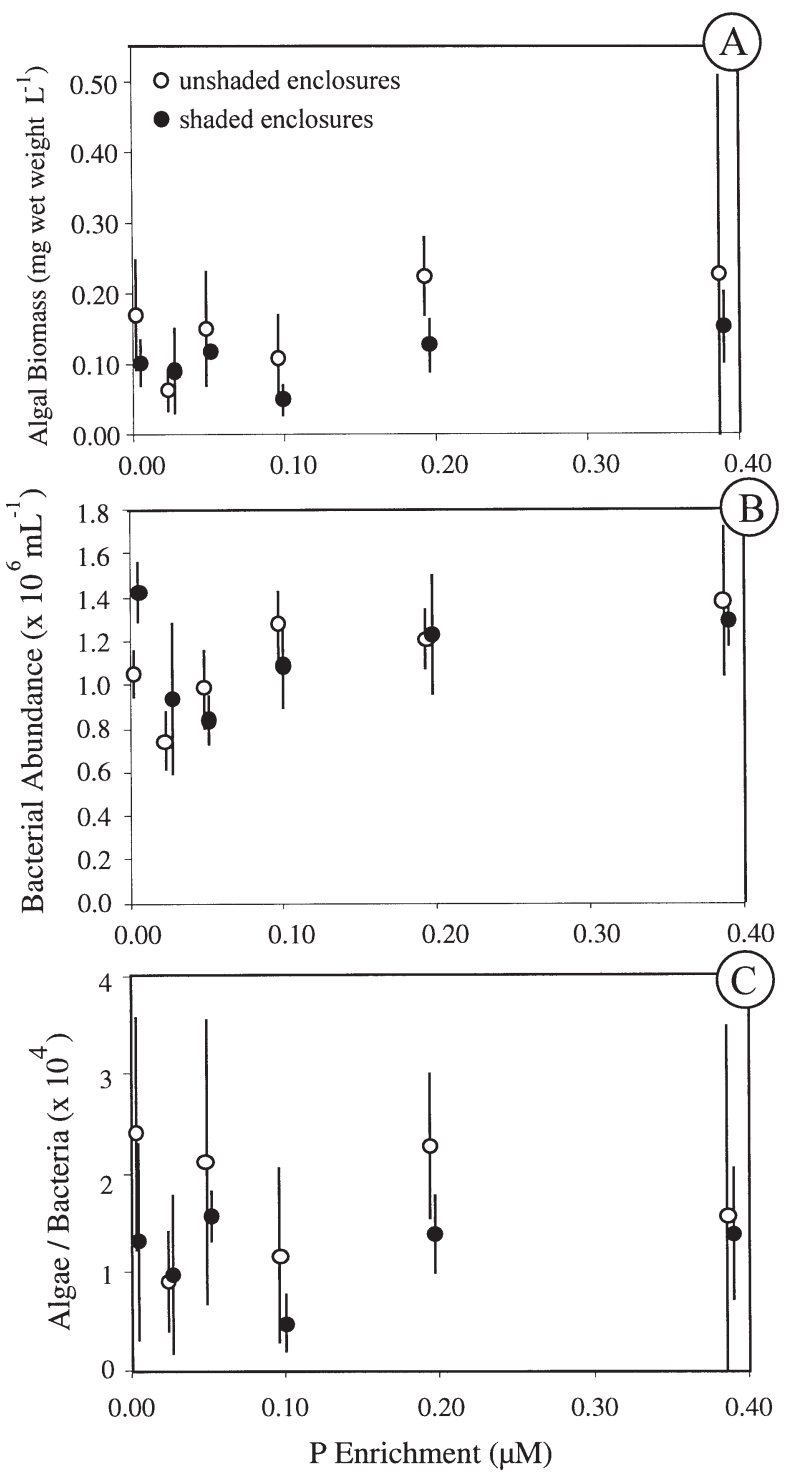

Fig. 3. Effects of experimental manipulations on (A) algal biomass (as determined by direct microscopic enumeration), (B) bacterial numbers (as determined by direct epifluorescent enumeration), and (C) the relative abundance of algae and bacteria. Confidence limits as in Fig. 1

\section{Balance of micro- and macrozooplankton}

Data for total macrozooplankton biomass in shaded and unshaded enclosures were analyzed and presented by Urabe et al. (2002b). In brief, total zooplankton biomass increased with P-fertilization in both unshaded and shaded enclosures. However, macrozooplankton biomass was significantly depressed in unshaded enclosures relative to shaded enclosures at low P-enrichment due to poor food quality. In contrast, at high P-enrichment zooplankton in unshaded enclosures exceeded zooplankton in shaded enclosures, likely due to lower total algal abundance and produc- tion under low light. As in our other analyses, data for HNF abundances for the final 3 sampling dates (Days 205, 210 and 215) were used. Visual examination indicated that there were no systematic differences in HNF cell size as a function of nutrient enrichment or irradiance and so HNF densities reasonably approximate HNF biomass in the enclosures. Unlike the observed increases in macrozooplankton biomass with P-fertilization, the abundance of HNF declined significantly with P-fertilization (Fig. 4A) in both shaded ( $\mathrm{p}<0.004$, $\left.\mathrm{R}^{2}=0.91\right)$ and unshaded $\left(\mathrm{p}<0.04, \mathrm{R}^{2}=0.72\right)$ enclosures (P-enrichment was $\ln +1$ transformed prior to regression to stabilize the variance around the regression). There was no consistent effect of light treatment on HNF abundance (Fig. 4A); indeed, the relationships between HNF abundance and P-enrichment level in unshaded and shaded treatments had nearly identical slopes (-89 vs -84 , respectively) and intercepts (303 vs 305). To evaluate potential shifts in the balance of
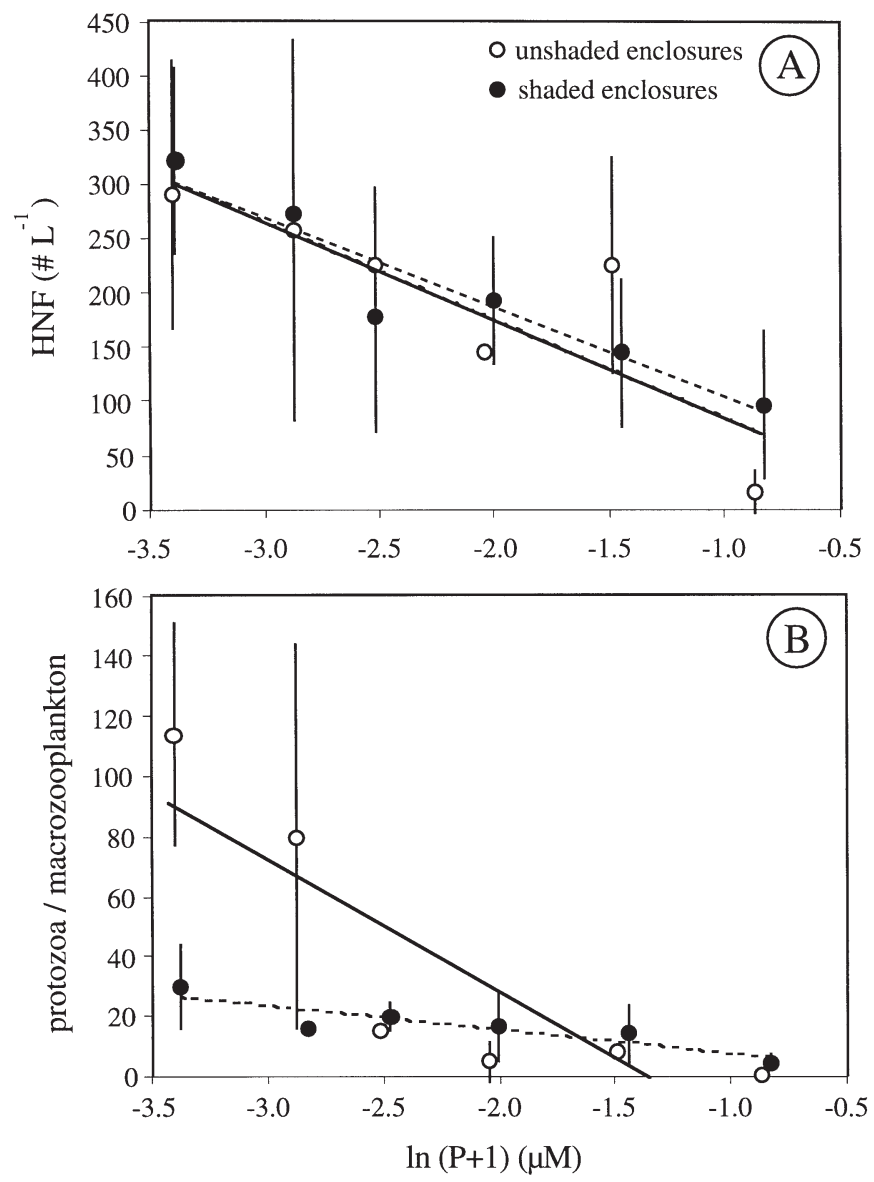

Fig. 4. Effects of experimental manipulations on (A) the abundance of heterotrophic nanoflagellates (HNF) and (B) the ratio of HNF abundance and macrozooplankton biomass. Data for macrozooplankton came from Urabe et al. (2002b). Confidence limits as in Fig. 1 
microbial and grazing food chains in the enclosures as a function of light and enrichment treatments, we calculated the ratio of HNF abundance to macrozooplankton biomass for each sampling date and analyzed the mean value of that parameter over 2 of the final 3 sampling dates (Days 205 and 210; data for macrozooplankton were not available for Day 215). Reflecting the simultaneous decrease in HNF abundance (Fig. 4A) and increase in macrozooplankton biomass (Urabe et al. 2002b) with P-fertilization, the HNF:macrozooplankton ratio decreased significantly with P-enrichment, especially in the unshaded enclosures (Fig. 4B; $\mathrm{p}<0.05, \mathrm{R}^{2}>0.76$ for regressions with untransformed and natural-log transformed data for HNF:macrozooplankton ratio). The effect of light on HNF:macrozooplankton ratio appeared to depend on P-fertilization treatment, as this ratio was higher in unshaded enclosures at low P-enrichment levels but somewhat lower in unshaded enclosures at high Penrichment levels (this is somewhat difficult to discern on the linear $y$-axis in Fig. 4B). This shift in the HNF:macrozooplankton ratio with light primarily reflected the changing impact of light on macrozooplankton biomass. The effect of P-fertilization on abundance of microflagellates was independent of irradiance (Fig. 4A) but, as reported by Urabe et al. (2002b), reducing irradiance led to strong increases in macrozooplankton abundance at low P-enrichment (due to food quality effects) but modest decreases at high Penrichment. Thus, shaded enclosures had lower HNF:macrozooplankton ratios than unshaded enclosures at low P-enrichment but higher ratios at high Penrichment.

\section{Bioassay responses of algae}

Growth bioassays indicated that algal resource limitation was affected by the light and P manipulations imposed on the enclosures. The nature of algal response and the statistical significance of light and $\mathrm{P}$ treatments and light $\times \mathrm{P}$ interactions on algal growth are summarized in Table 1 . The results reveal some surprises. In the unshaded enclosures, adding $\mathrm{P}$ in bioassays significantly stimulated algal growth in only 1 enclosure, the highest P-enrichment treatment (+0.30 $\mu \mathrm{M}$ P enclosure). However, manipulation of light in the bioassay experiment had a positive effect in 3 unshaded enclosures (significance was marginal in 2 cases) across the range of enclosure P-enrichment and was inhibitory to algal growth in 1 case $(+0.024 \mu \mathrm{M} P$ enclosure). Thus, light paradoxically appeared to have a stronger stimulatory effect on algal growth than $\mathrm{P}$ in the unshaded enclosures. Responses to light in the shaded enclosures were less surprising, as bioassays revealed significant increases in growth due to increased light in all 6 experiments performed (Table 1). However, responses to P-enrichment were frequent in the shaded enclosures despite the apparent existence of light limitation: 5 of 6 experiments in shaded enclosures resulted in algal growth response to P-enrichment $(2$ of these were marginally significant, $0.05<\mathrm{p}<$ $0.10)$. Thus, while light clearly had a dominant role as a limiting factor for algae in the shaded enclosures, $\mathrm{P}$ appeared to be more important as a limiting factor in the shaded than in the fully illuminated enclosures, a surprising result.

To evaluate trends in relative growth limitation of algae we calculated an index of the degree of algal growth limitation by light or by $\mathrm{P}$ in each enclosure. Following Gurung et al. (1999), an index of P limitation $\left(L_{\mathrm{P}}\right)$ was calculated as the average of $\mu_{\mathrm{LP}}-\mu_{\mathrm{LC}}$ and $\mu_{\mathrm{EP}}-$ $\mu_{\mathrm{EC}}$ while an index of light limitation $\left(L_{\mathrm{L}}\right)$ was calculated as the average of $\mu_{\mathrm{LC}}-\mu_{\mathrm{EC}}$ and $\mu_{\mathrm{LP}}-\mu_{\mathrm{EP}}$. This neglects possible influences of light $\times \mathrm{P}$ interactions in the bioassays but makes the trends easier to analyze graphically. In general, growth responses in the bioassays were dominated by a single treatment main effect and the few interaction effects were relatively modest. Thus, this analysis captures how algal growth limitation shifted with enclosure P-enrichment and shading treatments. The plots indicate that, as expected, $L_{\mathrm{L}}$ was greater for shaded versus unshaded enclosures (Fig. 5), a result supported by a paired $t$-test comparing $L_{\mathrm{L}}$ for unshaded and shaded enclosures at particular Penrichment levels $(p<0.01)$. In addition, algal light limitation in shaded enclosures increased with enclosure P-enrichment (Fig. $5 ; \mathrm{p}<0.001, \mathrm{R}^{2}=0.96$ ). However, there was no tendency for $L_{\mathrm{L}}$ to change with increasing enclosure fertilization level in unshaded enclosures ( $p>0.85)$. Reflecting the surprising results of statistical analyses (Table 1), $L_{\mathrm{P}}$ was significantly higher in shaded than in unshaded enclosures (Fig. 5B; $\mathrm{p}<0.03$ in paired $t$-test) while $L_{\mathrm{P}}$ increased $(\mathrm{p}=0.05)$ with increasing enclosure $P$ fertilization only in unshaded enclosures (Fig. 5B). Finally, as expected, the strength of light limitation relative to $\mathrm{P}$ limitation of algal growth $\left(L_{\mathrm{L}}-L_{\mathrm{P}}\right)$ was generally higher in shaded enclosures (compare the relative magnitudes of $L_{\mathrm{L}}$ and $L_{\mathrm{P}}$ for shaded and unshaded enclosures in Fig. 5), especially for P-enrichments greater than $0.048 \mu \mathrm{M}$ P. However, this difference was only marginally significant ( $p<0.09$ in a paired $t$-test). The relative importance of light limitation (again, as indicated by the difference $L_{\mathrm{L}}$ $-L_{\mathrm{P}}$ ) increased with enclosure P-fertilization in shaded enclosures $\left(p<0.0001, R^{2}=0.97\right)$ but was not affected by P-fertilization in the unshaded enclosures $(p>0.45)$.

According to the LNH and prior work on interactions between light and nutrient limitation (Smith 1983, Healey 1985, Goldman 1986), algal C:nutrient ratio 
Table 1. Statistical analyses of algal growth responses and changes in overall seston C:P ratio and the C:P ratio of new seston production in enrichment bioassays performed at the end of the enclosure experiment. Responses to bioassay irradiance manipulation are indicated under L (incubation in the enclosure vs incubation at $0.5 \mathrm{~m}$ in the lake itself) while responses to bioassay P-enrichment (unamended control or enriched with $2 \mu \mathrm{MPO}_{4}$ ) are indicated under P. Significant treatment effects (p < 0.05) are indicated by ' + ' when the response parameter increased in response to the manipulation of that factor or by ' - ' when the response parameter decreased in response to manipulation of that factor. Marginally significant responses and interaction terms $(0.05 \leq p<0.10)$ are indicated by parentheses. ns $=$ non-significant $(p>0.10)$. Occurrence of significant $(p<0.05)$ light $\times P$ enrichment interaction terms are indicated under $\mathrm{L} \times \mathrm{P}$. Other significant interaction terms: A, Light lowered seston C:P in controls but increased C:P in $+\mathrm{P}$; effect was modest. B, Effect of $\mathrm{P}$ was slightly stronger when incubated in lake. C, New C:P decreased slightly with light in controls but increased in $+\mathrm{P}$ bottles. $\mathrm{D}$, Effect of $\mathrm{P}$ was (marginally) stronger when bottles were incubated in the lake. E, Effect of P was stronger when bottles were incubated in the lake. F, Effect of light was (marginally) stronger in controls relative to $+\mathrm{P}$ bottles. $\mathrm{G}$, Effect of $\mathrm{P}$ was negative in enclosure but positive in the lake. $\mathrm{H}$, Effect of light was (marginally) larger in controls than in $+\mathrm{P}$ bottles. I: Effect of P was (marginally) stronger when bottles were incubated in the lake

\begin{tabular}{|c|c|c|c|c|c|c|c|c|c|c|}
\hline \multirow{2}{*}{$\begin{array}{c}\mathrm{P} \\
\text { treatment }\end{array}$} & \multirow{2}{*}{$\begin{array}{l}\text { Light } \\
\text { treatment }\end{array}$} & \multicolumn{3}{|c|}{ Growth } & \multicolumn{3}{|c|}{ Final seston C:P } & \multicolumn{3}{|c|}{ New seston C:P } \\
\hline & & $\mathrm{L}$ & $\mathrm{P}$ & $\mathrm{L} \times \mathrm{P}$ & $\mathrm{L}$ & $\mathrm{P}$ & $\mathrm{L} \times \mathrm{P}$ & $\mathrm{L}$ & $\mathrm{P}$ & $\mathrm{L} \times \mathrm{P}$ \\
\hline$+0 \mu \mathrm{M}$ & Unshaded & $(+)$ & $\mathrm{ns}$ & ns & ns & - & ns & $(+)$ & - & ns \\
\hline$+0.024 \mu \mathrm{M}$ & Unshaded & - & ns & ns & ns & - & $\mathrm{A}$ & $(-)$ & - & ns \\
\hline$+0.048 \mu \mathrm{M}$ & Unshaded & \multicolumn{9}{|c|}{ (replicate lost; no statistics possible) } \\
\hline$+0.097 \mu \mathrm{M}$ & Unshaded & $\mathrm{ns}$ & ns & ns & ns & - & ns & ns & - & ns \\
\hline$+0.19 \mu \mathrm{M}$ & Unshaded & + & ns & ns & ns & - & ns & + & - & ns \\
\hline$+0.39 \mu \mathrm{M}$ & Unshaded & $(+)$ & + & $\mathrm{B}$ & + & - & ns & ns & - & $\mathrm{C}$ \\
\hline$+0 \mu \mathrm{M}$ & Shaded & + & + & (D) & + & - & ns & + & - & ns \\
\hline$+0.024 \mu \mathrm{M}$ & Shaded & + & + & $\mathrm{E}$ & + & - & ns & + & - & ns \\
\hline$+0.048 \mu \mathrm{M}$ & Shaded & + & + & ns & + & - & $(\mathrm{F})$ & + & - & ns \\
\hline$+0.097 \mu \mathrm{M}$ & Shaded & + & ns & $\mathrm{ns}$ & $\mathrm{ns}$ & - & ns & + & - & ns \\
\hline$+0.19 \mu \mathrm{M}$ & Shaded & + & $(+)$ & $\mathrm{G}$ & + & - & $(\mathrm{H})$ & + & - & ns \\
\hline$+0.39 \mu \mathrm{M}$ & Shaded & + & + & (I) & + & - & ns & + & - & ns \\
\hline
\end{tabular}

should vary negatively with the degree of algal light limitation. To examine this, we plotted initial seston $\mathrm{C}: \mathrm{P}$ in each bioassay versus $L_{\mathrm{L}}$ assessed for that bioassay, expecting a negative correlation. As anticipated, seston C:P in the enclosures was negatively associated with the degree of apparent light limitation of phytoplankton growth (Fig. $6 ; \mathrm{p}<0.003, \mathrm{R}^{2}=0.67$, after natural log-transformation of $L_{\mathrm{L}}$ ). Above an $L_{\mathrm{L}}$ value of $\sim 0.1$, seston C:P reached values approximating the Redfield ratio. In addition, the relationship appeared to be non-linear, with steep increases in seston C:P at low levels of light limitation $\left(L_{\mathrm{L}}<0.1\right)$. Thus, it appears that considerable alleviation of light limitation is required before seston C:P increases substantially. For shaded enclosures, increasing enclosure P-fertilization was associated with a shift from left to right in this figure but there was no indication in unshaded enclosures that nutrient enrichment per se influenced the position of different enclosures on this plot.

Because we also measured seston $\mathrm{C}$ and $\mathrm{P}$ in each bioassay bottle at the end of the incubations, we were also able to estimate the C:P of new seston produced $\left(\mathrm{C}: \mathrm{P}_{\text {new }}\right)$ during the bioassay. Bioassay $\mathrm{P}$ enrichment inevitably lowered C: $\mathrm{P}_{\text {new }}$ (Table 1) to values of $\sim 30$ to 75 ; this response is not surprising given the high per capita P-supply in the P-enriched dilution bottles. In contrast, raising light (LC vs EC, LP vs EP) generally led to increased C: $\mathrm{P}_{\text {new }}$ (Table 1). This effect was significant in 5 of 6 experiments for shaded enclosures but only for 1 of 5 experiments involving unshaded enclosures. To consider the effect of enclosure irradiance and bioassay irradiance on the stoichiometry of algal production, we calculated mean $\mathrm{C}: \mathrm{P}_{\text {new }}$ for each unenriched bioassay treatment combination for each enclosure (that is, the mean values of $\mathrm{C}: \mathrm{P}_{\text {new }}$ for $\mathrm{LC}$ and $\mathrm{EC}$ treatments). We pooled all enclosure data for various enclosure enrichment levels for each irradiance treatment and performed a 2-way ANOVA ( $\mathrm{C}: \mathrm{P}_{\text {new }}$ was natural log-transformed to stabilize the variance) to evaluate the effects of enclosure irradiance (shaded vs unshaded) and bioassay irradiance (in enclosure vs in lake) manipulations on $C: P_{\text {new }}$. Data for $C: P_{\text {new }}$ for bottles incubated inside the enclosure clearly show that algae in fully illuminated enclosures were forming new biomass at a higher C:P ratio relative to algae growing in shaded enclosures (Fig. 7). Not surprisingly, C:P $\mathrm{P}_{\text {new }}$ in unshaded enclosures did not respond very strongly to the modest increase in irradiance when enclosure plankton were incubated at $0.5 \mathrm{~m}$ depth in L239. However, C: $\mathrm{P}_{\text {new }}$ for shaded enclosures increased dramatically when enclosure plankton were incubated in L239 (Fig. 7), reaching values even higher than those seen for unshaded enclosures. Thus, in the 2-way ANOVA for $\mathrm{C}: \mathrm{P}_{\text {new }}$ enclosure treatment (unshaded vs shaded) and enclosure-bioassay treatment interactions were statistically significant $(p<0.05)$. Examination of the data for individual 

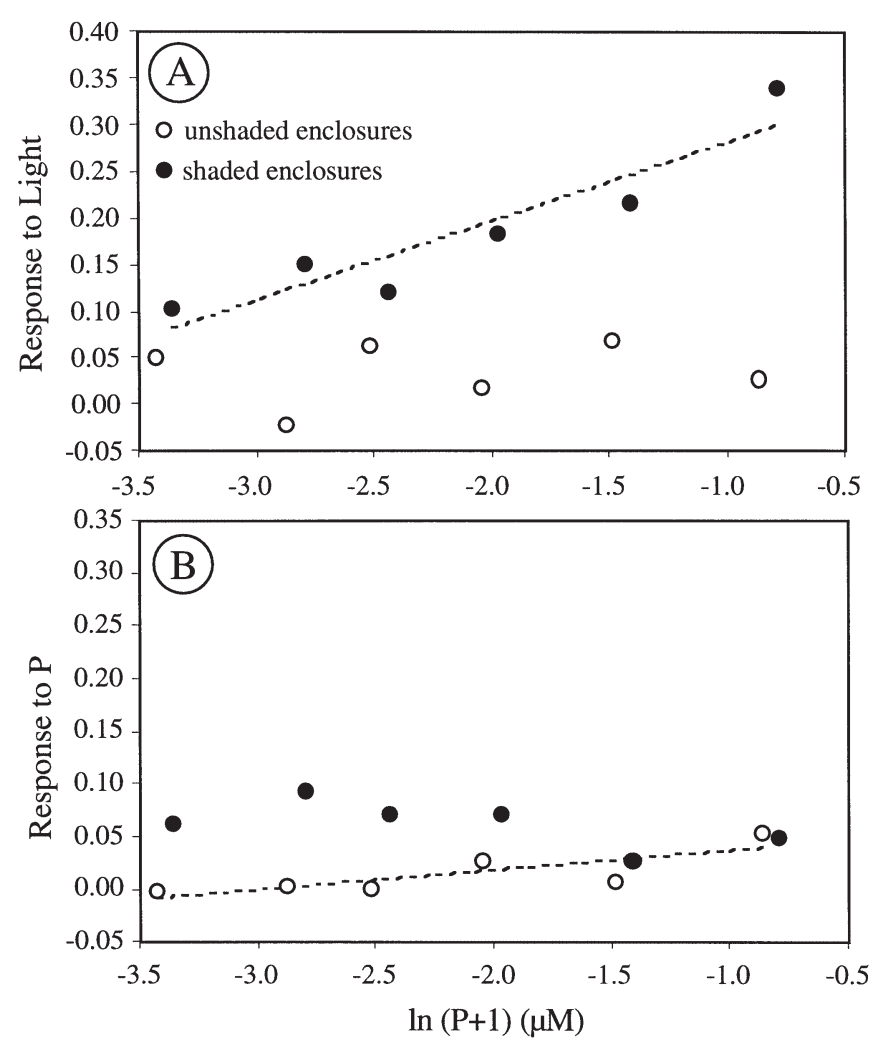

Fig. 5. Shifts in algal growth responses to (A) light enrichment $\left(L_{\mathrm{L}}\right.$ i incubation at $0.5 \mathrm{~m}$ depth in Lake 239 relative to incubation at $1 \mathrm{~m}$ depth in their respective enclosure) and (B) to $\mathrm{P}$ enrichment $\left(L_{\mathrm{P} i}+2 \mu \mathrm{M} \mathrm{PO}_{4}\right)$ at the end of the enclosure experiment. $L_{\mathrm{L}}$ calculated as average difference in algal growth when bottles incubated at relatively high light in lake vs in enclosure; average involved responses in unenriched bottles $\left(\mu_{\mathrm{LC}}-\mu_{\mathrm{EC}}\right)$ and responses in P-enriched bottles $\left(\mu_{\mathrm{LP}}-\mu_{\mathrm{EP}}\right) . L_{\mathrm{P}}$ for each enclosure was calculated as average difference in algal growth for P-enriched vs unenriched bottles; average involved data from bottles incubated at relatively high light in lake $\left(\mu_{\mathrm{LP}}-\mu_{\mathrm{LC}}\right)$ and from bottles incubated in enclosure $\left(\mu_{\mathrm{EP}}-\mu_{\mathrm{EC}}\right)$. Results of statistical tests of algal responses to light or P-enrichment are given in Table 1. (----) Results of regression analysis of $L_{\mathrm{L}}$ for shaded enclosures and $L_{\mathrm{P}}$ for unshaded enclosures, the only relationships that were statistically significant (enrichment treatment was ln +1 transformed to normalize the variance)

enclosures suggested that the responsiveness of $\mathrm{C}: \mathrm{P}_{\text {new }}$ to incubation location (enclosure vs L239) for shaded enclosures increased with enclosure P-enrichment $(\mathrm{p}=$ $\left.0.09, R^{2}=0.55\right)$. Thus, it appeared that algae growing in enclosures with the greatest likelihood of light limitation (shaded, high P-enrichment) developed a carbon fixation overcapacity that resulted in stoichiometrically unbalanced production of new biomass when irradiance was increased. In summary, these responses clearly show that the C:P stoichiometry of production of new biomass in L239 is sensitive to both P supply and irradiance experienced by the phytoplankton.

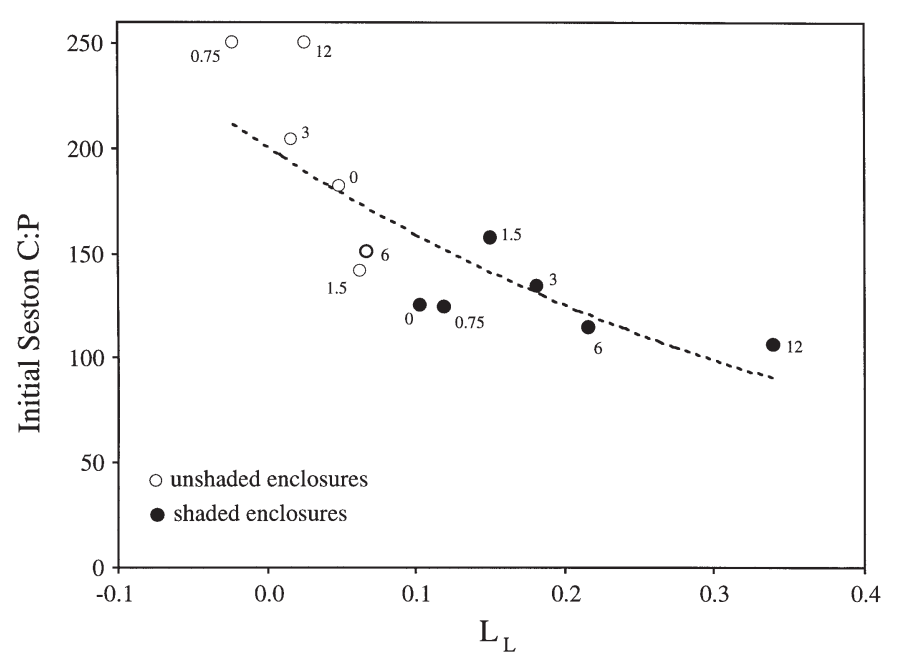

Fig. 6. Correlation between initial seston C:P ratio in bioassay bottles and the degree of light limitation $\left(L_{\mathrm{L}}\right)$ exhibited during the bioassay. $L_{\mathrm{L}}$ calculated as average increase in growth rate of algal seston (caught on GF/C filters) in elevated vs ambient irradiance treatments. P-fertilization treatment for each data point is shown. (----) Results of regression analysis on lntransformed data for initial seston C:P $\left(p<0.003, R^{2}=0.61\right)$

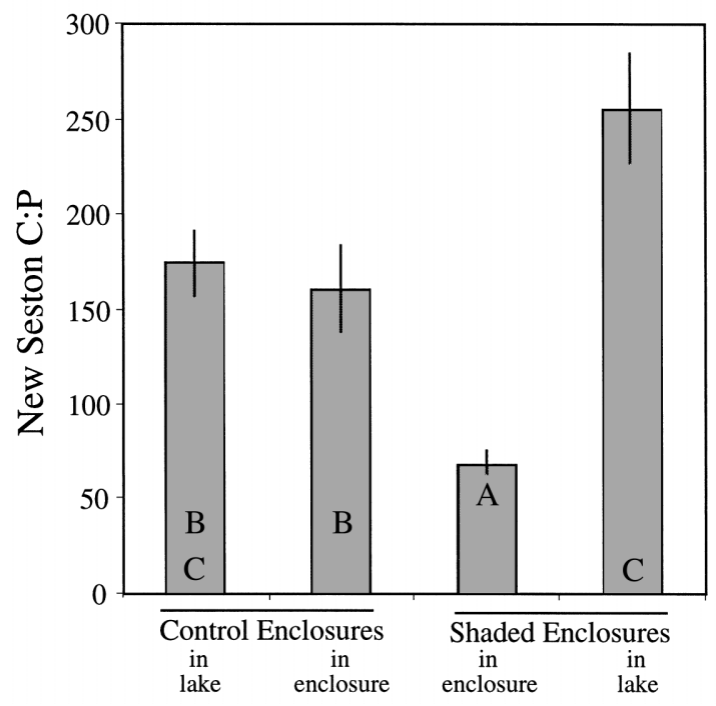

Fig. 7. C:P ratio of 'new' seston produced in bioassay bottles incubated under different conditions of illumination using sample water from unshaded and shaded enclosures. Data for all P-enrichment treatments were pooled (there was no statistically significant effect of $\mathrm{P}$ enrichment on $\mathrm{C}: \mathrm{P}_{\text {new }}$ in either irradiance treatment). Error bars indicate \pm 1 SE. Two-way ANOVA indicated significant effect of bioassay incubation treatment (incubation in enclosure vs in lake), no effect of enclosure treatment (unshaded vs shaded), but significant bioassay incubation $\times$ enclosure treatment interaction. Letters on each bar reflect results of Scheffe's multiple comparison test following the ANOVA; different letters indicate means significantly different from each other $(p<0.05)$ 
Table 2. Statistical analyses of bacterial growth responses in enrichment bioassays performed at the end of the enclosure experiment. Responses to DOC addition (unamended control or enriched with $250 \mu \mathrm{M} \mathrm{C}$ as glucose and acetate) are indicated under DOC, while responses to bioassay P-enrichment (unamended control or enriched with $2 \mu \mathrm{M} \mathrm{PO}_{4}$ ) are indicated under P. Significant treatment effects $(\mathrm{p}<0.05)$ are indicated by ' + ' when the response parameter increased in response to the manipulation of that factor or by '-' when the response parameter decreased in response to manipulation of that factor. Marginally significant responses and interaction terms $(0.05 \leq p<0.10)$ are indicated by parentheses. ns = non-significant $(p>0.10)$. Occurrence of significant $(p<0.05)$ DOC $\times$ $\mathrm{P}$-enrichment interaction terms are indicated under DOC $\times \mathrm{P}$. Other significant interaction terms: A, DOC stimulatory with P but inhibitory without P. B, P inhibitory without DOC but stimulatory with DOC

\begin{tabular}{|c|c|c|c|c|}
\hline \multirow{2}{*}{$\begin{array}{c}\mathrm{P} \\
\text { treatment }\end{array}$} & \multirow{2}{*}{$\begin{array}{l}\text { Light } \\
\text { treatment }\end{array}$} & \multicolumn{3}{|c|}{ Growth } \\
\hline & & DOC & $\mathrm{P}$ & $\mathrm{DOC} \times \mathrm{P}$ \\
\hline$+0 \mu \mathrm{M}$ & Unshaded & ns & ns & A \\
\hline$+0.024 \mu \mathrm{M}$ & Unshaded & ns & + & ns \\
\hline$+0.048 \mu \mathrm{M}$ & Unshaded & ns & ns & ns \\
\hline$+0.097 \mu \mathrm{M}$ & Unshaded & $(+)$ & ns & ns \\
\hline$+0.19 \mu \mathrm{M}$ & Unshaded & ns & + & ns \\
\hline$+0.39 \mu \mathrm{M}$ & Unshaded & + & $(-)$ & (B) \\
\hline$+0 \mu \mathrm{M}$ & Shaded & ns & + & ns \\
\hline$+0.024 \mu \mathrm{M}$ & Shaded & $(+)$ & + & ns \\
\hline$+0.048 \mu \mathrm{M}$ & Shaded & ns & ns & ns \\
\hline$+0.097 \mu \mathrm{M}$ & Shaded & + & + & ns \\
\hline$+0.19 \mu \mathrm{M}$ & Shaded & $(+)$ & ns & ns \\
\hline$+0.39 \mu \mathrm{M}$ & Shaded & + & + & ns \\
\hline
\end{tabular}

\section{Bioassay responses of bacteria}

Bacteria in the enclosures responded to addition of both $\mathrm{DOC}$ and $\mathrm{PO}_{4}$ in various enclosures but there were few significant $\mathrm{DOC} \times \mathrm{PO}_{4}$ interactions in the experiments (Table 2). Following the approach for algal bioassay response, for each bioassay an index of bacterial DOC limitation $\left(L_{\mathrm{DOC}}\right)$ was calculated as the average of $\mu_{\mathrm{DOC}}-\mu_{\mathrm{C}}$ and $\mu_{\mathrm{DOC}+\mathrm{P}}-\mu_{\mathrm{P}}$ while a similar index of bacterial P-limitation $\left(L_{\mathrm{P}}\right)$ was calculated as the average of $\mu_{\mathrm{P}}-\mu_{\mathrm{C}}$ and $\mu_{\mathrm{DOC}+\mathrm{P}}-\mu_{\mathrm{DOC}}$. In shaded enclosures, addition of DOC had a significant or marginally significant effect on bacterial growth rate in 4 of the 6 bioassays but DOC effects were observed in only 1 of the 5 bioassays in the fully illuminated enclosures (Table 2). However, a paired $t$-test comparing $L_{\text {DOC }}$ for shaded and unshaded enclosures was not statistically significant ( $p>0.85$ ), largely due to high variation in $L_{\mathrm{DOC}}$ among the unshaded enclosures. Statistically significant stimulation of bacterial growth by added $\mathrm{P}$ occurred in 4 of the 6 experiments in the shaded enclosures (Table 2) but in only 2 of the 6 experiments in the unshaded enclosures (there was also a significant decrease in growth to P-enriched bottles in the $+0.30 \mu \mathrm{M} P$ enclosure). There was no clear tendency of bacterial P-limitation to change as a function of P-fertilization level (regression analyses of $L_{\mathrm{P}}$ for bacteria against P-fertilization were non-significant, $\mathrm{p}>0.20$ ) nor was there any significant effect of irradiance on bacterial $\mathrm{P}$ response (paired $t$-test, $\mathrm{p}>$ 0.65). Visual examination indicated no consistent effect of bioassay treatments on bacterial cell size; thus, treatment effects on growth rates determined by cell counts probably reflected changes in overall bacterial production.

\section{DISCUSSION}

The main results of our study are summarized in a diagram that semi-quantitatively depicts the status of major planktonic pools and regulatory interactions under contrasting conditions of light and $\mathrm{P}$ input imposed in our enclosures (Fig. 8). Here we summarize the 4 scenarios illustrated there:

(1) Under high light and low P supply (i.e. unshaded enclosures receiving no experimental nutrient input), a pelagic community with high $\mathrm{C}: \mathrm{P}$ ratio in overall seston as well as in bacteria-sized particles occurred (Fig. 8A). Algal biomass was high relative to bacterial biomass and neither algae nor bacteria responded significantly to bioassay enrichments of nutrients or energy (light, DOC). Macrozooplankton biomass was low and representation of high P taxa such as Daphnia was diminished (Urabe et al. 2002b); therefore, C:P ratio of zooplankton biomass was high. Macrozooplankton growth was constrained by stoichiometric food quality with low growth efficiency in terms of $\mathrm{C}$ (Urabe et al. 2002b). Hence, macrozooplankton grazing was weak, microzooplankton (as indexed by HNF in our study) probably experienced modest grazing losses, and thus had relatively high biomass despite potentially poorer quality (high C:P) of bacterial prey. As a result, a dominant trophic pathway in this system probably involved DOC transfer from algae to bacteria and subsequent consumption of bacteria by microzooplankton with strong dissipation of excess $\mathrm{C}$ by microzooplankton due to stoichiometric imbalance with their bacteria prey.

(2) Under low P but low light (Fig. 8B), shifts in both stoichiometric aspects and biomass pools were observed. Algal biomass was decreased somewhat but was also more P-rich. Signs of algal light limitation were observed, as expected. However, somewhat paradoxically, growth rates of both algae and bacteria responded to P-enrichment, perhaps reflecting a decrease of overall availability of $\mathrm{P}$ to phytoplankton and bacteria due to the large increase in the biomass and P-content of the macrozooplankton community (Urabe et al. 2002b). Stoichiometric limitation of 
Fig. 8. Changes in major components of the planktonic food web under contrasting conditions of light and nutrient balance. Scenarios summarize data from this study and for whole seston and macrozooplankton from Urabe et al. (2002b). (A-D) Sizes of boxes indicate approximate magnitude of biomass of particular functional groups; absolute sizes of boxes for different functional groups (e.g. macrozooplankton vs macrozooplankton under high light, low P) are not meant to be compared directly, as we do not have direct measurements of the absolute biomass levels of all of the functional groups depicted. Dark shading within each box indicates relative P-content of that pool. A grey box is used to indicate microzooplankton because we do not have data on their P-content. Indications of likely relative magnitude of particular fluxes and of efficiency of trophic transfers (in terms of gross growth efficiency, or the fraction of ingested $\mathrm{C}$ that is transformed to new biomass production) are included. Also, indication is given of primary limiting factors for algae (light, phosphorus) and bacteria (DOC, phosphorus). Z = macrozooplankton; $\mathrm{M}=$ microzooplankton; $\mathrm{A}=$ algae; $\mathrm{B}=$ bacteria; $\mathrm{P}=\mathrm{PO}_{4}$

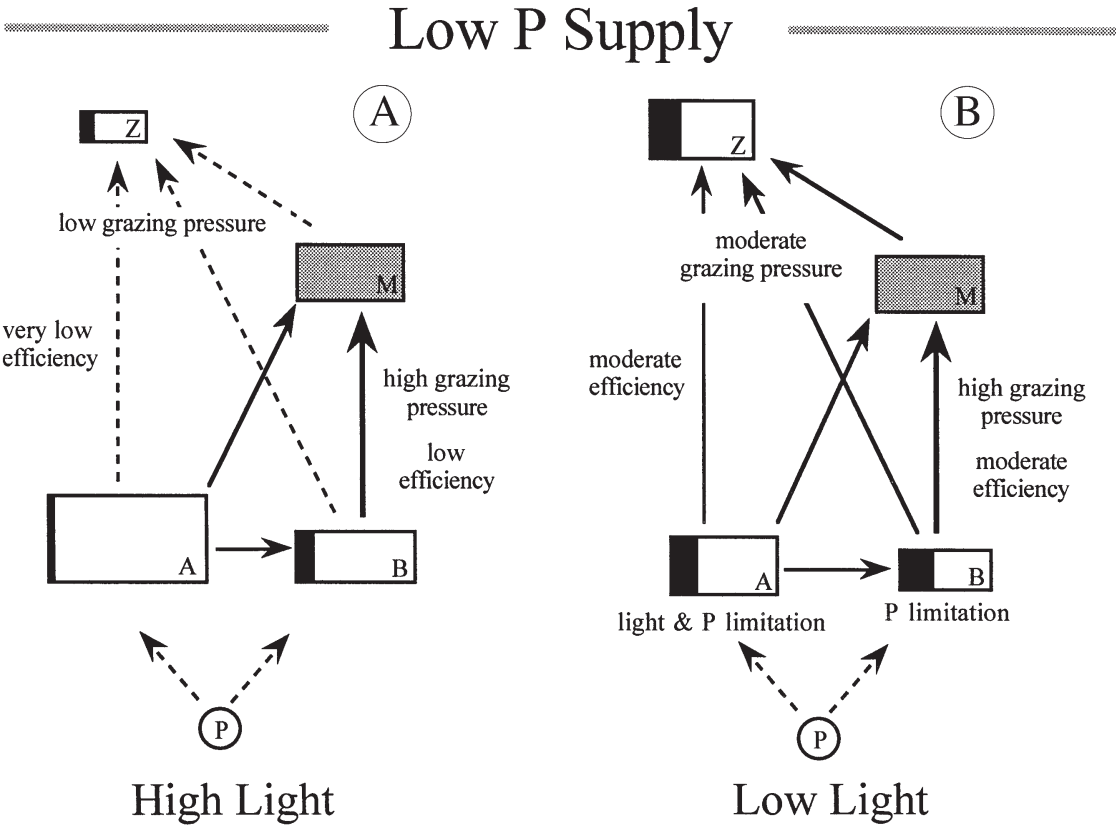

\section{High P Supply}

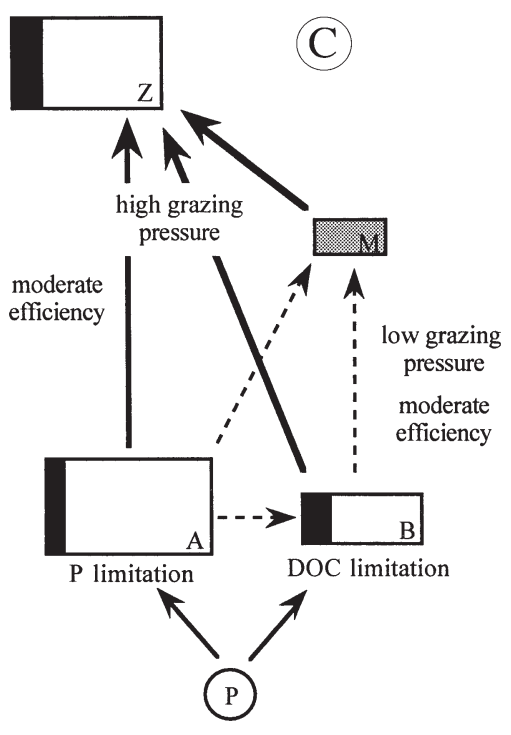

High Light

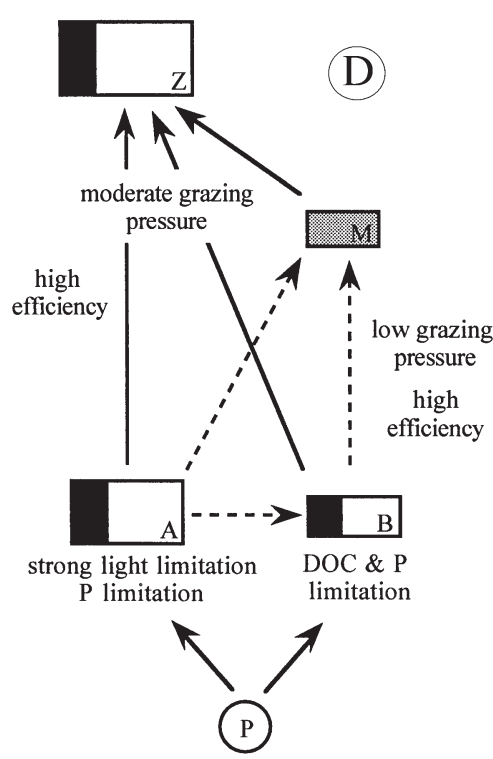

Low Light macrozooplankton production was relieved by shading, resulting in greater zooplankton production and growth efficiency in terms of C (Urabe et al. 2002b). Despite higher macrozooplankton biomass that probably imposed high loss rates, microzooplankton biomass was unchanged (relative to unshaded enclosures), perhaps due to more efficient growth in response to increased P-content of bacterial prey. Important pathways of trophic flow involved both direct links and indirect links (i.e. via bacteria and microzooplankton) to macrozooplankton.

(3) At high rates of P-input and ambient light (Fig. 8C), strong shifts in both biomass and stoichiometry were also observed relative to ambient light and nutrient conditions. Inorganic P levels, as indicated by SRP, were higher than at low P-input. The absolute and relative abundances of algae and bacteria were largely unchanged compared to unenriched conditions 
but seston C:P ratios, both overall and in bacteria-sized particles, were significantly decreased. While algal growth surprisingly responded only to P-enrichment despite elevated P-input levels, bacterial growth rates were not DOC-limited, as expected. Again, perhaps the increased sink of $\mathrm{P}$ in massively larger biomass of P-rich macrozooplankton (Urabe et al. 2002b) was responsible for continued P-limited algal growth rate despite increased P-inputs. Large increases in macrozooplankton due to relief of stoichiometric constraints and increased growth efficiency were accompanied by strongly decreased abundance of microzooplankton. Thus, in this condition the dominant trophic links primarily involved direct macrozooplankton consumption of algal and bacterial production.

(4) To a large degree these responses to increased P input were even more pronounced at low light input (Fig. 8D). Here, algal biomass was decreased due to shading but seston $\mathrm{C}: \mathrm{P}$ ratios were quite low. Algae experienced strong light limitation (along with a weaker response to P-enrichment) while bacteria responded to both DOC and P-amendment. Zooplankton biomass was somewhat lower than in the fertilized, unshaded enclosures, perhaps due to lower overall food abundance. Microzooplankton abundance was also low relative to low enrichment enclosures. Thus, dominant trophic pathways probably involved direct links to macrozooplankton under these conditions.

Our study represents the first large-scale field experiment to test microbial aspects of the LNH of Sterner et al. (1997) and has produced the following primary findings consistent with these aspects:

(1) The relative abundance of macrozooplankton over microzooplankton was significantly affected by both irradiance and nutrient supply. In particular, fertilization led to increases in macrozooplankton abundance (Urabe et al. 2002b), decreases in HNF abundance (Fig. 4A), and thus to a major increase in the relative abundance of macrozooplankton versus HNF as P-enrichment increased (Fig. 4B). It appears that relieving stoichiometric constraints on macrozooplankton production in L239 induced a massive shift in the pathways of organic matter processing between the grazing chain and the microbial food web, implying that in L239 and similar unproductive lakes, light:nutrient balance affects microzooplankton primarily through 'top down' effects. P-enrichment did not lead to increased abundances of heterotrophic nanoflagellates in the enclosures. On the contrary, abundance of these microzooplankton declined dramatically in high $\mathrm{P}$ enclosures, in concert with large increases in macrozooplankton induced by the improved stoichiometric food quality due to P-fertilization (Urabe et al. 2002b). This suggests that microzooplankton abundance in L239 is strongly determined by the proliferation of macrozooplankton and that the effects of light:nutrient balance on microzooplankton are indirect and occur mainly via the impacts of light:nutrient balance on food quality for larger grazers. However, there is some suggestion that HNF success was also influenced by stoichiometric food quality, as has been suggested in laboratory studies (Nakano 1994, Rothaupt 1996). That is, in low $\mathrm{P}(+0 \mu \mathrm{M} \mathrm{P}$, $+0.024 \mu \mathrm{M}$ P) enclosures, HNF abundances in shaded and unshaded enclosures were nearly identical (Fig. 4A), despite the fact that macrozooplankton biomass was 2 to 4 times higher in shaded enclosures (Urabe et al. 2002b) and that HNF in those enclosures probably experienced higher loss rates. Thus, HNF growth rates were probably higher in shaded enclosures to compensate for those losses, perhaps in response to a more suitable food quality (lower C:P in overall seston and in bacteria-sized $<1 \mu \mathrm{m}$ particles) induced by shading. Unfortunately, we cannot assess this possibility in the absence of direct assessments of HNF growth rates.

(2) Both irradiance and P-fertilization generally affected algal resource limitation (Fig. 5) and the C:P of new algal biomass formed (Fig. 7) in expected ways (but see below), in that decreased light resulted in increased prevalence of light limitation and lower $\mathrm{C}: \mathrm{P}_{\text {new }}$ while P-enrichment increased the magnitude of light limitation (in shaded enclosures) and lowered $\mathrm{C}: \mathrm{P}_{\text {new }}$. Enclosure shading interacted with P-fertilization to have a large effect on the responsiveness of algal stoichiometry to light; algae from shaded enclosures under high P-enrichment greatly increased their C:P when incubated in full sunlight (Fig. 7). Finally, one component of the LNH of Sterner et al. (1997) relies on an argument that decreased irradiance decreases the overall severity of algal growth limitation, and thus C:nutrient ratio, by reducing the physiological demand for nutrients established by algal growth capacity $\left(\mu_{\mathrm{m}}\right)$. Thus, we expected that algae in low light enclosures would exhibit low $\mu_{\mathrm{m}}$ when released from potential nutrient limitation. To assess this we used growth rate in the P-enriched bottles incubated in the enclosures (i.e. $\mu_{\mathrm{EP}}$ ) to estimate $\mu_{\mathrm{m}}$. Indeed, values of $\mu_{\mathrm{EP}}$ were nearly twice as high in the unshaded enclosures as in shaded enclosures (0.13 vs $0.07 \mathrm{~d}^{-1}$, data not shown; $\mathrm{p}<0.04$ in a pairwise $t$-test). Enclosure P-enrichment level had no effect on $\mu_{\mathrm{m}}(\mathrm{p}>$ 0.50 in regression of $\mu_{\mathrm{m}}$ vs P-enrichment treatment).

(3) Irradiance and P-fertilization affected bacteria mostly by altering their physiological state (as indexed by the relative frequency of bioassay responses and by $<1 \mu \mathrm{m}$ seston C:P in shaded and unshaded enclosures), not by affecting their population size or standing biomass. More specifically, shading appeared to ameliorate bacterial $\mathrm{P}$ limitation, as indicated by lower $<1 \mu \mathrm{m}$ 
seston C:P in the shade and by the increased frequency of DOC responses (relative to responses to P) in bioassays in shaded enclosures (Table 2). In addition, P-enrichment lowered $<1 \mu$ m seston C:P in both unshaded and shaded enclosures. The impact of light on bacterial C:P is particularly interesting, as it emphasizes a close linking between the nutritional states of algae and bacteria in the enclosures. However, manipulations of light and $\mathrm{P}$ supply had relatively modest impact on the magnitudes and relative importance of DOC and P limitation of bacterial growth. The relative constancy of bacterial abundance despite strong manipulations of light and nutrients may reflect the nature of our assessment of the microbial community, which involved total direct counts and did not evaluate any physiological or phylogenetic shifts within the assemblage. Previous studies using direct epifluorescent counts also report only relatively modest responses of total bacterial abundance to manipulations of nutrients because grazing on bacteria can mask changes in growth (Pace \& Cole 1996); studies using more sophisticated techniques capable of assessing different strains or taxa of microbes in the community would give a more sensitive assessment of the microbial response to alteration in light:nutrient balance. However, such effects are unlikely to have influenced our data related to microbial limiting factors, as our growth bioassays involved dilutions which reduced grazing on bacteria by $75 \%$ and thus we were probably able to observe effects on growth rate more directly for at least the dominant members making up the bacterial assemblage.

Nevertheless, some of our observations are at odds with predictions derived from the LNH. Specifically, decreasing light or increasing nutrient supply (or the combination of the two) did not decrease the dominance of bacteria relative to algae as expected (Sterner et al. 1997). On the contrary, lowering irradiance resulted in reductions in algal biomass but no change in bacterial abundance; thus, algae had greater relative abundance in the fully illuminated enclosures, irrespective of $\mathrm{P}$ enrichment level. This discrepancy is particularly interesting, as our bioassay and C:P data suggest that algal and bacterial physiological condition were affected in ways generally consistent with the LNH. Bacteria seemed to be more consistently limited by DOC in shaded enclosures while algae were more strongly limited by light in shaded enclosures and under high P-enrichment. The discrepancy potentially arises because predictions from the LNH about relative algal and bacterial dominance consider only the qualitative direction of the outcome of competitive relations between the 2 functional groups and do not consider any other indirect effects on trophic pathways that might be induced simultaneously by shifts in light:nutrient balance. However, our light and nutrient manipulations produced massive changes in the absolute and relative abundances of macro- and microzooplankton (Urabe et al. 2002b, Fig. 4) and thus there were also likely to have been major changes in grazing losses experienced by algae and bacteria. Unfortunately, we do not have data to evaluate these relative impacts. The original formulation of the $\mathrm{LNH}$ did not incorporate such indirect effects mediated by changes in loss processes to algae and bacteria; our data suggest that a more complicated formulation including these 'top-down' effects is probably necessary to reflect how the relative abundances of algae and bacteria shift with light:nutrient balance.

Also at odds with the LNH are some aspects of algal growth responses to P-enrichment in the bioassay experiments. First, lowering irradiance did not ameliorate algal responsiveness to P-enrichment as expected, even as the bioassay response to light and overall seston C:P declined in expected ways as discussed above. On the contrary, algal response to $\mathrm{P}$ addition in bioassays was consistently stronger in shaded enclosures than in fully illuminated enclosures at each enclosure P-fertilization level (Fig. 5). This apparent increase in the overall scarcity of $\mathrm{P}$ under strongly diminished irradiance is somewhat paradoxical, especially given the coincident responses in seston C:P stoichiometry and light limitation. One explanation for this outcome is that increased biomass of P-rich macrozooplankton under low light and high P-inputs (Urabe et al. 2002b) increased the sink strength for P in this pool (Andersen 1997), thus removing circulating $P$ from the plankton community. Alternatively, increased algal P-limitation under low light suggests a strong interaction between irradiance and $\mathrm{P}$ demands in which lower light raises the P-requirement of the algae. However, there is little evidence in the existing literature on algal physiological ecology that would lead one to expect such a response.

In summary, the bulk of our data support various aspects of the hypothesis of Sterner et al. (1997), that variation among lakes in seston C:P stoichiometry and thus in pelagic food web structure is driven by changes in light:nutrient balance. Manipulations of light and $\mathrm{P}$ supply altered algal and bacterial physiological state and C:P stoichiometry; these changes had major consequences for the planktonic food web in the form of reciprocal impacts on macrozooplankton (Urabe et al. 2002b) and microzooplankton. However, some aspects of the LNH were not supported, such as shifts in the relative dominance of algae versus bacteria biomass. Factors responsible for the considerable inertia of this balance remain enigmatic. Nevertheless, documentation of effects of light:nutrient balance on food web dynamics has now been accomplished in experimental 
systems ranging in scale from laboratory flasks (Urabe \& Sterner 1996), indoor microcosms (Sterner et al. 1998, Urabe et al. 2002a), and field enclosures with natural plankton communities (Urabe et al. 2002b, this study). It remains to be seen whether the applicability of these mechanisms continues to hold at increasing scales, as one extrapolates to whole ecosystems where a myriad of factors vary both spatially and temporally. However, field studies involving multi-lake comparative analysis (Sterner et al. 1997) and temporal dynamics at fixed stations (Karl 1999) suggest that hydrodynamic alterations affecting the relative supplies of light and nutrient supply impinge at least on seston C:N:P stoichiometry. Ramifications for the food web at these larger scales remain generally unexplored.

Acknowledgements. We thank P. Frost, J. Clasen, A. Waggener, C. Yoshimizu and the staff of the Experimental Lakes Area, Freshwater Institute, Canada, for their technical and logistical support. J. Cotner and 2 anonymous reviewers provided invaluable comments on the manuscript. This work was performed as a Japan-USA joint science study and supported by grant-in-aid from JSPS and IGBP-MESSC-JPN to J.U. and NSF grant DEB-9725867 to J.J.E.

\section{LITERATURE CITED}

Andersen T (1997) Pelagic nutrient cycles: herbivores as sources and sinks. Springer-Verlag, Berlin

APHA (American Public Health Association) (1992) Standard methods for the examination of water and wastewater, 18th edn. APHA, Washington, DC

Azam F, Fenchel T, Field JG, Grey JS, Meyer-Reil LA, Thingstad F (1983) The ecological role of water-column microbes in the sea. Mar Ecol Prog Ser 10:257-263

Berman-Frank I, Dubinsky Z (1999) Balanced growth in aquatic plants: myth or reality? BioScience 49:29-37

Bratbak G, Thingstad TF (1985) Phytoplankton-bacteria interactions: an apparent paradox? Analysis of a model system with both competition and commensalism. Mar Ecol Prog Ser 25:23-30

Carlsson P, Caron DA (2001) Seasonal variation of phosphorus limitation of bacterial growth in a small lake. Limnol Oceanogr 46:108-120

Caron DA (1983) Technique for enumeration of heterotrophic and phototrophic nanoplankton, using epifluorescence microscopy, and comparison with other procedures. Appl Environ Microbiol 46:491-498

Chrzanowski TH, Grover JP (2001) The light:nutrient ratio in lakes: a test of hypothesized trends in bacterial nutrient limitation. Ecol Lett 4:453-457

Chrzanowski TH, Sterner RW, Elser JJ (1995) Nutrient enrichment and nutrient regeneration stimulate bacterioplankton growth. Microb Ecol 29:221-230

Chrzanowski TH, Kyle M, Elser JJ, Sterner RW (1997) Element ratios and growth dynamics of bacteria in an oligotrophic Canadian shield lake. Aquat Microb Ecol 11: 119-125

Cole JJ (1999) Aquatic microbiology for ecosystem scientists: new and recycled paradigms in ecological microbiology. Ecosystems 2:215-225

Corzo A, Morillo JA, Rodriguez S (2000) Production of trans- parent exopolymer particles (TEP) in cultures of Chaetoceros calcitrans under nitrogen limitation. Aquat Microb Ecol 23:63-72

Cotner JB, Biddanda BA (2002) Small players, large role: microbial influence on auto-heterotrophic coupling and biogeochemical processes in aquatic ecosystems. Ecosystems 5:105-121

Cotner JB Jr, Wetzel RG (1992) Uptake of dissolved inorganic and organic phosphorus compounds by phytoplankton and bacterioplankton. Limnol Oceanogr 37:232-243

Cotner JB, Ammerman JW, Peele ER, Bentzen E (1997) Phosphorus-limited bacterioplankton growth in the Sargasso Sea. Aquat Microb Ecol 13:141-149

Currie DJ, Kalff J (1984) The relative importance of bacterioplankton and phytoplankton in phosphorus uptake in freshwater. Limnol Oceanogr 29:311-321

Elser JJ, Chrzanowski TH, Sterner RW, Schampel JH, Foster DK (1995a) Elemental ratios and the uptake and release of nutrients by phytoplankton and bacteria in three lakes of the Canadian Shield. Microb Ecol 29:145-162

Elser JJ, Stabler LB, Hassett RP (1995b) Nutrient limitation of bacterial growth and rates of bacterivory in lakes and oceans: a comparative study. Mar Microb Food Webs 9: $105-110$

Elser JJ, Hayakawa H, Urabe J (2001) Nutrient limitation reduces food quality for zooplankton: Daphnia response to seston phosphorus enrichment. Ecology 82:898-903

Ferrier Pages C, Rassoulzadegan F (1994) N-remineralization in planktonic protozoa. Limnol Oceanogr 39:411-418

Findlay DL, Kling HJ (1998) Protocols for monitoring biodiversity: phytoplankton in fresh waters. Ecological Monitoring and Assessment Network Web Site; available at: www.cciw.ca/eman-temp/research/protocols/freshwater/ phyto/

Goldman JC (1986) On phytoplankton growth rates and particulate $\mathrm{C}: \mathrm{N}: \mathrm{P}$ ratios at low light. Limnol Oceanogr 31: 1358-1363

Grover JP (1997) Resource competition. Chapman \& Hall, London

Grover JP (2000) Resource competition and community structure in aquatic microorganisms: experimental studies of algae and bacteria along a gradient of organic carbon to inorganic phosphorus supply. J Plankton Res 22: 1591-1610

Güde H (1989) The role of grazing on bacteria in plankton succession. In: Sommer U (ed) Plankton ecology: succession in plankton communities. Springer-Verlag, New York, p 337-364

Guerrini F, Mazzotti A, Boni L, Pistocchi R (1998) Bacterialalgal interactions in polysaccharide production. Aquat Microb Ecol 15:247-253

Gurung TB, Urabe J, Nakanishi M (1999) Regulation of the relationship between phytoplankton Scenedesmus acutus and heterotrophic bacteria by the balance of light and nutrients. Aquat Microb Ecol 17:27-35

Healey FP (1985) Interacting effects of light and nutrient limitation on the growth rate of Synechococcus linearis (Cyanophyceae). J Phycol 21:134-146

Hwang SJ, Heath RT (1997) The distribution of protozoa across a trophic gradient, factors controlling their abundance and importance in the plankton food web. J Plankton Res 19:491-518

Jürgens K (1994) Impact of Daphnia on planktonic microbial food webs - a review. Mar Microb Food Webs 8:295-324

Jürgens K, Pernthaler J, Schalla S, Amann R (1999) Morphological and compositional changes in a planktonic bacterial community in response to enhanced protozoan grazing. 
Appl Environ Microbiol 65:1241-1250

Karl DM (1999) A sea of change: biogeochemical variability in the North Pacific Subtropical Gyre. Ecosystems 2:181-214

Lancelot C (1983) Factors affecting phytoplankton extracellular release in the Southern Bight of the North Sea. Mar Ecol Prog Ser 12:115-121

Langenheder S, Jürgens K (2001) Regulation of bacterial biomass and community structure by metazoan and protozoan predation. Limnol Oceanogr 46:121-134

Larsen A, Castberg T, Sandaa RA, Brussaard CPD and 6 others (2001) Population dynamics and diversity of phytoplankton, bacteria and viruses in a seawater enclosure. Mar Ecol Prog Ser 221:47-57

Morris DP, Lewis WM (1992) Nutrient limitation of bacterioplankton growth in Lake Dillon, Colorado. Limnol Oceanogr 37:1179-1192

Nakano S (1994) Carbon:nitrogen:phosphorus ratios and nutrient regeneration of a heterotrophic flagellate fed on bacteria with different elemental ratios. Arch Hydrobiol 129:257-271

Obernosterer I, Herndl GJ (1995) Phytoplankton extracellular release and bacterial growth: dependence on the inorganic N:P ratio. Mar Ecol Prog Ser 116:247-257

Pace ML, Cole JJ (1996) Regulation of bacteria by resources and predation tested in whole-lake experiments. Limnol Oceanogr 41:1448-1460

Porter KG, Feig YS (1980) The use of DAPI for identifying and counting aquatic microflora. Limnol Oceanogr 25: 943-948

Rothaupt KO (1992) Stimulation of phosphorus-limited phytoplankton by bacterivorous flagellates in laboratory experiments. Limnol Oceanogr 37:750-759

Rothaupt KO (1996) Utilization of substitutable carbon and phosphorus sources by the mixotrophic chrysophyte Ochromonas sp. Ecology 77:706-715

Sanders RW, Wickham SA (1993) Planktonic protozoa and metazoa: predation, food quality, and population control. Mar Microb Food Webs 7:197-223

Schindler DW (1977) Evolution of phosphorus limitation in lakes. Science 195:260-262

Schindler DW (1998) Replication vs. realism: the need for ecosystem-scale experiments. Ecosystems 1:323-334

Schindler DW, Fee EJ, Ruszczynski T (1978) Phosphorus input and its consequences for phytoplankton standing crop and production in the Experimental Lakes Area and in similar lakes. J Fish Res Board Can 35:190-196

Sherr EB, Sherr BF (1991) Planktonic microbes - tiny cells at

Editorial responsibility: David Karl,

Honolulu, Hawaii, USA the base of the ocean's food webs. Trends Ecol Evol 8: $50-54$

Shuter B (1979) A model of physiological adaptation in unicellular algae. J Theor Biol 78:519-552

Smith VH (1983) Light and nutrient dependence of photosynthesis by algae. J Phycol 19:306-313

Solorzano L (1969) Determination of ammonia in natural waters by the phenolhypochlorite method. Limnol Oceanogr 14:799-801

Stainton MP, Capel MJ, Armstrong FAJ (1977) The chemical analysis of fresh water, 2nd edn. Can Fish Mar Serv Misc Spec Publ 25:vii + p 166

Sterner RW (1994) Seasonal and spatial patterns in macro and micro nutrient limitation in Joe Pool Lake, Texas. Limnol Oceanogr 39:535-550

Sterner RW, Hessen DO (1994) Algal nutrient limitation and the nutrition of aquatic herbivores. Annu Rev Ecol Syst 25 $1-29$

Sterner RW, Chrzanowski TH, Elser JJ, George NB (1995) Sources of nitrogen and phosphorus supporting the growth of bacterio- and phytoplankton in an oligotrophic Canadian shield lake. Limnol Oceanogr 40:242-249

Sterner RW, Elser JJ, Fee EJ, Guildford SJ, Chrzanowski TH (1997) The light:nutrient ratio in lakes: the balance of energy and materials affects ecosystem structure and process. Am Nat 150:663-684

Sterner RW, Clasen J, Lampert W, Weisse T (1998) Carbon:phosphorus stoichiometry and food chain production. Ecol Lett 1:146-150

Urabe J, Sterner RW (1996) Regulation of herbivore growth by balance of light and nutrients. Proc Natl Acad Sci USA 93:8465-8469

Urabe J, Watanabe Y (1992) Possibility of N or P limitation for planktonic cladocerans: an experimental test. Limnol Oceanogr 37:244-251

Urabe J, Elser JJ, Kyle M, Sekino T, Kawabata Z (2002a) Herbivorous animals can mitigate unfavorable ratios of energy and material supplies by enhancing nutrient recycling. Ecol Lett 5:177-185

Urabe J, Kyle M, Makino W, Yoshida T, Andersen T, Elser JJ (2002b) Reduced light increases herbivore production due to stoichiometric effects of light:nutrient balance. Ecology 83:619-627

Vadstein O (2000) Heterotrophic, planktonic bacteria and cycling of phosphorus: phosphorus requirements, competitive ability, and food web interactions. Adv Microb Ecol $16: 115-167$

Submitted: July 10, 2002; Accepted: September 10, 2002 Proofs received from author(s): January 30, 2003 